\title{
Leyes de pureza ritual en judeoespañol: entre la normativa rabínica y las prácticas de las mujeres*
}

\author{
Katja Šmid ** \\ ILC, CCHS - CSIC, Madrid
}

\begin{abstract}
Este artículo ofrece un estudio de algunas de las leyes, costumbres y consideraciones morales acerca de la pureza ritual de la mujer judía. Para ello, se recopilan textos tomados de las obras halájicas escritas en judeoespañol por el autor sefardí Eli'éźer Šem Tob Papo (Sarajevo, ? - Jerusalén, 1898), más en concreto, del Séfer Damésec Eli 'éźer: Yoré de á (Belgrado, 1865) y Séfer Damésec Eli 'éźer: Yoré de á (Jerusalén, 1884). Los textos normativos recogidos interpretan el fenómeno de la menstruación desde la perspectiva rabínica. Al mismo tiempo revelan algunas prácticas de las mujeres sefardíes del Imperio otomano, relacionadas con la separación entre hombre y mujer durante el periodo de impureza, la cuenta de siete días limpios, la inspección corporal, los preparativos para la inmersión y la purificación en el baño ritual.
\end{abstract}

PALABRAS Clave: pureza ritual; menstruación; baño ritual; micvé; mujeres; literatura rabínica sefardí; judeoespañol; Eli 'éźer Šem Tob Papo.

Laws of Ritual Purity in Judeo-Spanish: Rabbinic Laws and Women's Practices.- The aim of this article is to examine some laws, customs and moral teachings related to ritual purity of Jewish women, based on the recopilation of texts from two halakhic works written in Judeo-Spanish by the Sephardic author Eli'ezer Shem Tov Papo (Sarajevo, ? - Jerusalem, 1898), in particular, Sefer Damesek Eli 'ezer: Yoreh de 'ah (Belgrade, 1865), and Sefer Damesek Eli' ezer: Yoreh de'ah (Jerusalem, 1884). The halakhic texts commented in the article interpret the phenomenon of menstruation from a rabbinic point of view. At the same time the texts reveal some practices carried out by Sephardic women in the Ottoman Empire, in reference to the separation of men and women during the period of impurity, the counting of the seven clean days, corporal examination, and preparations for ritual immersion.

KeYwords: Ritual Purity; Menstruation; Ritual Bath(ing); Mikveh; Women; Sephardic Rabbinic Literature; Judeo-Spanish; Eli'ezer Shem Tov Papo.

* El presente estudio se ha llevado a cabo en el marco del proyecto de investigación del Plan Nacional I+D+i: «Sefarad siglo XXI (2009-2011): Edición y estudio filológico de textos sefardíes» (SGPI, MICINN FF2009-10672 [subprograma FILO]). El artículo es resultado del proyecto postdoctoral sobre la obra Yoré de á (Jerusalén, 1884) de Eli 'éźer Papo, en curso, gracias a un contrato JAE doc (2010-2013) en el CCHS-CSIC. Me gustaría agradecer a los evaluadores anónimos de este artículo por sus referencias, comentarios e ideas.

***katja.smid@cchs.csic.es 
Si bien algunos estudios importantes han llamado la atención acerca de la mujer sefardí en el Imperio otomano ${ }^{1}$, todavía quedan por estudiar muchas fuentes judeoespañolas de distintas épocas en las que los propios autores sefardíes testimonian su visión de la mujer judía, cuyo estudio puede mejorar considerablemente nuestro conocimiento al respecto. Siendo especialmente escasos los escritos acerca de la vida religiosa de la mujer sefardí ${ }^{2}$ he seleccionado para este artículo los materiales relativos a algunos rituales realizados por las judías, tal como están expresados en algunas obras populares de la literatura rabínica judeoespañola de la segunda mitad del siglo XIX.

Se estudia aquí el corpus de textos sefardíes relativos a las leyes de pureza familiar tomado de la literatura religiosa producida por el rabino Eli 'éźer Šem Tob Papo (Sarajevo, ? - Jerusalén, 1898) ${ }^{3}$, autor de cuatro

\footnotetext{
${ }^{1}$ Además de numerosos artículos, véanse, a modo de ejemplo, las siguientes colectáneas recientes en las que aparecen estudios sobre la mujer judía y sefardí: T. ALEXANDER (ed.), Gender and Identity [= El Prezente, Studies in Sephardic Culture 3] (Be'er Sheva: Ben Gurion University Press, 2009); Y. Moreno Koch / R. IzQuierdo Benito (coords.), Hijas de Israel, mujeres de Sefarad: de las aljamas de Sefarad al drama del exilio. XVIII Curso de Cultura Hispanojudía y Sefardí de la Universidad de Castilla-La Mancha (Cuenca: Ediciones de la Universidad de Castilla-La Mancha, 2010); y P. Díaz-Mas / M. SÁnCHEZ PÉREZ (eds.), Los sefardies ante los retos del mundo contemporáneo: identidad y mentalidades (Madrid: CSIC, 2010), 257-303.

${ }^{2}$ De libros de oraciones para mujeres sefardíes se han ocupado, entre otros, M. Lazar (ed.), Siddur tefillot: A Woman's Ladino Prayer Book (Lancaster: Labyrinthos, 1995); O. (Rodrigue) Schwarzwald, «Two Sixteenth-Century Ladino Prayer Books for Women», European Judaism 43 (2010), 37-51; EAD., «Linguistic Features of a Sixteenth Century Women's Ladino Prayer Book: The Language used for Instructions and Prayers», en Selected Papers from the Fifteenth British Conference on Judeo-Spanish Studies, H. Pomeroy / C. J. Pountain / E. Romero (eds.) (London: Department of Iberian and Latin American Studies, Queen Mary, University of London, 2012), 247-260; EAD., Sidur para mujeres en ladino. Salónica, siglo XVI. Edición anotada y traducida (Jerusalem: Ben Zvi Institute, 2012); D. M. BunIs, «The East-West Sephardic Láaz (Judeo-Spanish) Dialect Dichotomy as Reflected in Three Editions of Séfer Dat yehudit by Abraham Laredo and Yishhạac Haleví», en Estudios sefardíes dedicados a la memoria de Iacob M. Hassán (z"l), E. Romero / A. García Moreno (eds.) (Madrid: CSIC, 2011), 157-190.
}

${ }^{3}$ Acerca de su vida, vid. M. D. Gaon, Yehudé hamiźraḥ beerês Yisrael (Jerusalén: Azriel, 1937), vol. II, 535; J. MAEstro, «Prilog Sarajlija rabinskoj književnosti», Jevrejski Glas 15/670 (1939), 2-3; D. M. BunIs, «Elements of Hebrew and Balkan Origin in the Terminology of Foodways in R. Eliezer ben Šem Tov Papo's Sefer Damesek Eliezer. Judezmo Rabbinical Literature as a Linguistic and Folkloristic Resource. Part One» [en 
manuales halájicos judeoespañoles escritos en aljamía hebraica y otras tres obras halájicas escritas en lengua hebrea ${ }^{4}$. Papo pertenece al grupo de rabinos sefardíes del siglo XIX que se dedicaron a proporcionar a su pueblo la enseñanza religiosa tradicional en la lengua vernácula. Sus libros estaban destinados al sefardí medio del Imperio otomano cuya lengua de comunicación era el judeoespañol y cuyo conocimiento del hebreo probablemente se limitaba al entendimiento de los textos litúrgicos.

Es especialmente importante su legado literario en judeoespañol consistente en las siguientes obras extensas: Séfer Damésec Eli ézéer: Órah hayim (Belgrado, 1862, reeditada en Esmirna, 1877), recopilación de preceptos generales y relativos al calendario y a las festividades ${ }^{5}$; Séfer Damésec Eli éźer: Yoré de 'á (Belgrado, 1865), compendio de normas particulares relativas a la muerte y al duelo (hb. abelut) ${ }^{6}$; Séfer Méšec betí (Sarajevo, 1872-74), manual de las leyes específicas relativas a la fiesta del šaḅat ${ }^{7}$ y Séfer Damésec Eli éźer: Yoré de 'á (Jerusalén, 1884), colección de leyes relativas a la mujer ${ }^{8}$.

hebreo], Jerusalem Studies in Jewish Folklore 5-6 (1984), 151-195; Ž. LEBL, Jevrejske knjige štampane u Beogradu 1837-1905 (Gornji Milanovac: Dečje novine, 1990), 39; E. Romero, La creación literaria en lengua sefardí (Madrid: Mapfre, 1992), 108-109, 111; I. M. Hassán, «La prosa rabínica», en Sefardíes: Literatura y lengua de una nación dispersa. XV Curso de Cultura Hispanojudía y Sefardí de la Universidad de Castilla-La Mancha, E. Romero (ed.) / I. M. Hassán / R. Izquierdo Benito (coords.) (Cuenca: Ediciones de la Universidad de Castilla-La Mancha, 2008), 265-300: 267-268, 270-272, 291292, 297; y K. ŠMID, El Séfer Méšec betí, de Eliézer Papo: Ritos y costumbres sabáticas de los sefardíes de Bosnia (Madrid: CSIC, 2012), 39-46.

${ }^{4}$ Séfer Hésed veemet (Belgrado, 1865), Séfer Apé źutré (Sarajevo, 1875), y Séfer Damésec Eli éźer (Jerusalén, 1892).

${ }^{5}$ Vid. Maestro, «Prilog», 2-3; Bunis, «Elements», 151-195; LeBL, Jevrejske knjige, 102; Romero, Creación, 108-109; M. B. Lehmann, Ladino Rabbinic Literature and Ottoman Sephardic Culture (Bloomington: Indiana University Press, 2005), 132; Hassán, «Prosa», 265-300: 267-268, 270-272, 291-292; y ŠMID, Séfer, 47-49.

${ }^{6}$ Vid. MAestro, «Prilog», 2; Bunis, «Elements», 156; LeBL, Jevrejske knjige, 112; y ŠMID, Séfer, 49-50.

${ }^{7}$ Vid. Maestro, «Prilog», 3; BunIS, «Elements», 156; Romero, Creación, 111; HasSÁN, «Prosa», 265-300: 297; y ŠMID, Séfer.

${ }^{8}$ Vid. BunIs, «Elements», 156-157; RoMERo, Creación, 109; y ŠMID, Séfer, 50-51; EAD., «Tiempos antiguos y tiempos modernos: la mujer sefardí bosnia en dos obras judeoespañolas», Verba Hispanica 20 (2012), 359-374, y EAD., «Yoré de’á de Eli ézer Papo: un compendio judeoespañol del siglo XIX de normas para mujeres sefardíes», Ladinar 7 (en prensa). 
Tres de sus obras llevan títulos compuestos por dos partes distintas. La primera parte del título Damésec Eli éźer es una cita parcial del versículo bíblico de Génesis 15:2 que alude al nombre del autor ${ }^{9}$. Las segundas partes de los títulos se inspiran en los tratados Órah hayim y Yoré de á de la codificación de la Ley judía por antonomasia Šulhán 'aruj de Yosef Caro (1488-1575), establecidos ya en la codificación halájica Arba 'á turim por Ya‘acob ben Ašer (1270-1340). Papo adapta al judeoespañol solo los primeros dos tratados del Šulhán 'aruj, distribuyendo los preceptos relevantes para el público general del tratado Órạ hayim en sus obras Séfer Damésec Eli éźer: Órạ hayim (Belgrado, 1862 y Esmirna, 1877) y Séfer Méšec betí (Sarajevo, 1872-74) ${ }^{10}$, y los del Yoré de 'á en sus obras que llevan el mismo título Séfer Damésec Eli éźer: Yoré de 'á (Belgrado, 1865 y Jerusalén, 1884) ${ }^{11}$.

Se trata de manuales halájicos populares caracterizados por un contenido normativo y ético-moral variado y que se encuadran dentro del marco de la literatura rabínica sefardí. Por una parte, incluyen materiales halájicos normativos, morales y literarios: es decir, normas, preceptos, oraciones en ladino, minhaguim o costumbres (religiosas) locales, enseñanzas y valores ético-morales del judaísmo tradicional, y, finalmente, ma'asiyot o relatos judíos con moraleja. Por otra parte, también contienen materiales costumbristas: usos y costumbres locales de la época, datos históricos, geográficos y culturales sobre los sefardíes del Imperio otomano, datos relativos a la cultura material de la época, descripciones acerca de la vida pública y privada de la minoría sefardí en la sociedad otomana de finales del siglo XIX y otros.

\footnotetext{
${ }^{9}$ Según la traducción de Bajar Hayım en Séfer Arḅa 'á ve esrim (Viena, 1813) el versículo completo dice: «Dio, ¿qué darás a_mí? y yo andán sólo y varón de goberno de mi caśa el damésec Eli 'éźer». En dicho versículo se entabla un diálogo entre Dios y Abraham en el que el patriarca expresa el miedo de morir sin hijos a pesar de que Dios le ha prometido tener descendientes directos, ya que el damasceno Eli éźer es sólo un criado.

${ }^{10}$ Sobre el título de la obra Séfer Méšec betí que también alude al versículo bíblico citado, vid. Šmid, Séfer, 55-57; EAD., «La casa sefardí según el Méšec betí», en Selected Papers from the Fifteenth British Conference on Judeo-Spanish Studies, H. PoMEroy I C. J. Pountain / E. Romero (eds.) (London: Department of Iberian and Latin American Studies, Queen Mary, University of London, 2012), 261-277: 261-262.

${ }^{11}$ Quedan sin traducir al judeoespañol los tratados Ében ha 'éźer y Hošen mišpat del Šulhán 'aruj.
} 


\section{LEYES DE PUREZA FAMILIAR Y SU IMPORTANCIA}

El conjunto de normas y leyes que regulan la vida sexual de un matrimonio -que forman parte de las leyes de pureza y modestia dentro de la compleja normativa religiosa judía-, se conocen, bien como leyes de pureza familiar o matrimonial (hb. taharat hamišpahá) ${ }^{12}$, bien como leyes de nị̣á (hb. '[mujer] menstruante), o bien como leyes de micvé (hb. 'estanque de agua para la purificación ritual por inmersión') '. Según esas prescripciones están prohibidas las relaciones sexuales durante el periodo de menstruación y los siete días siguientes. El periodo de purificación de la mujer concluye después del séptimo día limpio cuando la mujer debe realizar un baño ritual por inmersión. La observancia de estas normas es una de las obligaciones religiosas más importantes de la mujer judía ${ }^{14}$.

Las primeras prescripciones relativas a la pureza ritual femenina aparecen formuladas en el Levítico, y tratan de la impureza de la mujer parturienta (Le 12:2-5) y de la que emite flujo de sangre menstrual $\mathrm{u}$ otros

${ }^{12}$ Sobre la crítica de ese término vid. C. Fonrobert, Menstrual Purity: Rabbinic and Christian Reconstructions of Biblical Gender (Stanford: Stanford University Press, 2000), 29.

${ }^{13}$ Sobre otras leyes matrimoniales, vid. nota 55.

${ }^{14} \mathrm{El}$ fenómeno de la menstruación en el judaísmo y sus leyes ha sido ampliamente estudiado, sobre todo en décadas más recientes. Vid., por ejemplo, H. M. KAMSLER, «Hebrew Menstrual Taboos», The Journal of American Folklore 51/199 (1938), 76-82; B. GREENBERG, How to Run a Traditional Jewish Household (New York: Simon \& Schuster, 1983), 120-136; R. BIALE, Women and Jewish Law: An Exploration of Women's Issues in Halakhic Sources (New York: Schocken Books, 1984), 147-174; R. R. WASSERFALL (ed.), Women and Water: Menstruation in Jewish Life and Law (Hannover-London: Brandeis University Press, 1999); Fonrobert, Menstrual Purity; R. S. Sultan, A Rose of the Valley. A Compilation of the Laws of Family Purity According to the Sephardic Custom (New York: Sephardic Legacy Press, 2004); E. Fram, My Dear Daughter: Rabbi Benjamin Slonik and the Education of Jewish Women in Sixteenth-Century Poland (Cincinatti: Hebrew Union College Press, 2007); C. Caballero Navas, «Mujeres, cuerpos y literatura médica medieval en hebreo», Asclepio 60 (2008), 37-61: 49-55; EAD., «Medicine and Pharmacy for Women. The Encounter of Jewish Thinking and Practices with the Arabic and Christian Medical Traditions», European Review 16 (2008), 249-259: 255; EAD., «Palabras de rabinos, saberes de mujeres. Discursos normativos y prácticas sanitarias en torno a la menstruación», en Actes del Simposi Temps i espais de la Girona jueva (Girona: Patronat Call de Girona, 2011), 303-310; S. F. Koren, Foresaken: The Menstruant in Medieval Jewish Mysticism (Waltham, MA: Brandeis University Press, 2011); etc. 
flujos uterinos de sangre (Le 15:19-28). También se hace una breve mención de la prohibición de las relaciones sexuales con una mujer impura (Le 18:19) y el castigo que merece la transgresión de esta ley (Le 20:18). La normativa relativa a la impureza de la mujer menstruante y de la parturienta como a su purificación ha sido completada y comentada por los rabinos en la Mišná y el Talmud en el orden Taharot ('Purezas'), especialmente en los tratados Micvaot ('Baños rituales') y Niḍá ('Menstruante'). Más tarde estas normas han sido codificadas en distintos códigos de la Ley judía en hebreo, siendo el más importante de ellos el Šulhán 'aruj de Yosef Caro escrito en el siglo XVI, en los apartados Hiljot niḍá, es decir, leyes relativas a la menstruación (183-200) e Hiljot micvaot, leyes relativas a baños rituales (201-202).

Rabí Eli éźer Papo nos ofrece en sus cuatro manuales populares una selección representativa de las leyes rabínicas relativas a la pureza matrimonial en judeoespañol. La recopilación más extensa organizada en apartados dedicados exclusivamente a esa temática nos ha llegado a través de sus obras Séfer Damésec Eli éźer: Yoré de á (Jerusalén, 1884, hs. 30a35b) y Séfer Damésec Eli éźer: Yoré de á (Belgrado, 1865, hs. 67b-69b), mientras que en las obras Séfer Damésec Eli éźer: Órạ̣ ḥayim (Belgrado, 1862, reeditada en Esmirna, 1877, hs. 71b, 73b, 107a, 181a) y Séfer Méšec betí (Sarajevo, 1872-74, pp. 57, 188, 201, 238, 321) se refiere sólo esporádicamente a estas leyes de pureza familiar.

En el presente artículo los materiales se organizan en los siguientes bloques temáticos: 1) Cuestiones generales sobre menstruación; 2) Separación entre hombre y mujer durante el periodo de impureza; 3) Cuenta de siete días limpios e inspección; y 4) Purificación en el baño ritual por inmersión.

En su manual de preceptos sabáticos Séfer Méšec betí (Sarajevo, 1872-74) nos ofrece el autor la versión judeoespañola de un breve texto mišnaico que se lee en hebreo cada semana en el oficio litúrgico sinagogal de recepción del sábado (hb. caḅalat šaḅat). En el pasaje citado se advierte sobre tres transgresiones de la Ley por las cuales la mujer puede ser castigada con su muerte a la hora de dar a luz. Se trata de tres preceptos clave que deben cumplir las mujeres: la observancia de las leyes de pureza -que ocupa el primer lugar-; su obligación de separar y quitar una 
parte de la masa (hb. halá) preparada para hacer los panes sabáticos ${ }^{15}$; y el encendido de las velas en honor de esa fiesta ${ }^{16}$ :

Meldamos en la Mišná ${ }^{17}$ : por 3 pecados las mujeres se mueren en hora de su parir: porque non se acavidan a_guardar el dam niḍut como su din, y porque non se acavidan a_sacar la halá como su din, y porque non se acavidan en encedimiento de la candela de šabat. Ubataḥti $b^{\prime \prime} H^{18}$, que en sabiendo las mujeres que en pecados semejantes hay peligre de muerte, ḥ"v, asegún diǰimos de la Mišná, cierto que se acavidarán siendo las mujeres son acavidadas en las miŝvot más que los honbres [E. PAPO 1872-74: 188].

El rabino cree que recordando el citado pasaje de la Mišná las mujeres tendrán más cuidado en la observancia de las leyes mencionadas. De paso lanza en sus obras varias veces repetida opinión según la cual las mujeres, en general, son mucho más cumplidoras a la hora de guardar los preceptos religiosos que los hombres.

A modo de introducción a un extenso capítulo de la obra Damésec Eli éźer: Yoré de 'á (Jerusalén, 1884), en el que Papo recopila las leyes relativas a la mujer menstruante, el autor hace una observación interesante acerca de algunos jóvenes de su tiempo que se avergüenzan de mostrar públicamente su identidad judía, en ocasiones, incluso ante sus correligionarios. Por un lado, critica a los hombres que en un viaje en barco durante su rezo público se avergüenzan de ponerse las filacterias (hb. tefilín) y el manto ritual (hb. talit). Por otro lado, reprocha la actitud de algunas parejas judías que durante el período de la menstruación -cuando según las leyes de pureza ritual deben estar apartados uno del otro- disimulan este estado con su comportamiento no queriendo que los demás asocien sus actividades con su identidad religiosa:

${ }^{15}$ Las comidas que se celebran en el hogar en honor de la fiesta sabática comienzan con la bendición del vino (hb. Quiḍúš), seguida de la bendición Hamoŝí ('El que extrae [el pan de la tierra]'), que se pronuncia por los dueños de la casa sobre los panes trenzados (hb. halot). La obligación de la mujer consiste en preparar la masa para esos panes sabáticos y quitar de ella una cantidad pequeña (hb. halá), que será quemada, antes de hacer los panes y hornearlos.

${ }^{16}$ Es preceptivo el encendido de por lo menos dos velas por parte de las amas de casa antes del inicio del sábado.

${ }^{17}$ Mišná «Šaḅat» cap. 2 mišná 6.

${ }^{18}$ Hb. 'Tengo fe en Dios'. 
Šama'ti que agora b'av"h hay muchos baḥurim que non se acavidan y se dan de mano a mano siendo dićen que se avergüenzan de la gente que lo sepan todos que está aparte de su mujer y con verdad que es locura grande siendo que esta ĝente se avergüenzan de amostrar que son jiidiós afi' delantre de los ĵidiós, kol šekén que cuando están en el vapor o por camino que non meten talit ni tefilín. Enpero David hamélej diǰo «vaadaḅerá be edoteja négued melajim veló ebóš» ${ }^{19}$, y el ben adam es obligado de haćer asegún dijo el taná «hevé 'aź kanamer, vecal kanéšer, raŝ kaŝebí, vegiḅor kaarí la'asot reŝón abija šeḅašamáyim» ${ }^{20}$. Y para haćer las miŝvot del Šy"t non se avergüence de ninguno salvo descubra su brazo y meta tefilín y afirme lo_que dijo el pasuc «veraú kol 'amé haareŝ ki šem H' nicrá 'aleja vayirú mimeja» ${ }^{21}$, y kol šekén y c"v cuando está con jidiós que lo vean todos que es buen jiidió que afirma los acavidamientos que mos acavidaron hajamim, ź"l, cuando tiene a_su mujer niḍá [E. PAPO 1884: 30a].

Ese breve pasaje describe perfectamente la época de finales del siglo XIX a la que pertenecen el autor y sus lectores, cuando el saber y conocimiento del judaísmo tradicional en la minoría judía de la diáspora otomana comienzan a decaer y las sociedades en el espacio balcánico y centroeuropeo sufren una pronunciada modernización influida por las culturas europeas occidentales. En esta breve introducción a las leyes relativas a la pureza familiar el rabino confiesa su angustia ante las nuevas actitudes de jóvenes judíos a los que anima a que, a pesar de los tiempos modernos, cumplan los preceptos del judaísmo y muestren abiertamente que son buenos judíos, tanto ante su pueblo como ante los demás pueblos con los que conviven.

\section{Cuestiones Generales SOBRE MENSTRUación}

Papo explica algunas generalidades acerca de la emisión mensual de sangre por parte de las mujeres. En varias ocasiones subraya la diferencia que puede haber entre mujeres en el tiempo transcurrido desde una menstruación a otra, consistente en 20, 25 o 30 días:

${ }^{19}$ Sal 119:46 'y hablaré sobre tus testimonios delante de los reyes y no me avergonzaré'.

${ }^{20}$ Pirqué Abot 5:20: 'sé atrevido como el leopardo y liviano como el águila, veloz como el ciervo y fuerte como el león para hacer la voluntad de tu Padre que [está] en los cielos'.

${ }^{21}$ De 28:10 ‘y verán todos los pueblos de la tierra que el nombre del Señor es invocado sobre ti y te temerán'. 
Rob de las mujeres tienen tienpo tacsado que veen sangre: hay mujeres que veen de 20 diyas a 20 diyas, hay que veen de 25 a 25, y hay que veen de 30 diyas a 30 diyas. Y el rob de las mujeres es que veen de 30 diyas a 30 diyas [E. PAPO 1884: 31a].

Por un lado, nos ofrece en el siguiente pasaje la conocida interpretación rabínica acerca de la naturaleza de la menstruación. Explica que la sangre de la mujer mana de una fuente con la que metafóricamente se refiere a la matriz y usa la imagen del árbol que da flor de la que sale el fruto, vinculando la menstruación a la concepción y la maternidad ${ }^{22}$ :

El 'inián de esta sangre que les viene a_las mujeres es que el $\breve{S}^{\prime} y t$ vido con su hojojá la grande que el teba' del ben adam es de seer criyado de la sangre. Por esto criyó el ŠS"yt dientro de su cuerpo de la mujer un lugar que mana sangre de este lugar como el caynac de agua y nace esta sangre a_poco a_poco como las aguas en el caynac. Y como el árbol de fruta hay en él muchos frescores que de él salen las hojas y las flores y cayen del árbol y después saca fruto, ansí hay en la mujer muchas sangres que non es raúy para que se criye criyatura de ella. Y como las frutas del árbol cuando ya se amaduran cayen del árbol, ansí es el teba' de esta sangre cuando ya vino su tienpo que ya se amaduró le sale de su cuerpo. Y hay mujeres que se le amadura más presto en 20 diyas, hay quen en 25 , hay quen en 30 ; y esto se_llama véset [E. PAPO 1884: 31a].

En contraste, Papo nos ofrece en la siguiente cita una visión misógina sobre la impureza de la mujer menstruante que es considerada una de las más graves y puede transmitirse por cercanía o contacto en los niveles físico y espiritual ${ }^{23}$ :

\footnotetext{
${ }^{22}$ Esta metáfora es utilizada por Ibn al-Yazzar en su obra Zad al-Musafir, que fue traducida al latín por Constantino el Africano (Viaticum peregrinantis), y tuvo gran influencia en la obra ginecológica atribuida a Trótula. El Liber de sinthomatibus mulierum (parte del compendio atribuido a Trótula) recoge dicha metáfora, modificada: «scilicet menstrua, que uulgus apellat flores, quia sicut arbores non afferunt sine floribus fructus, sic mulieres sine suis floribus sue concepcionis officio defraudantur»; vid. M. H. Green, The Trotula: A Medieval Compendium of Women's Medicine (Philadelphia: University of Pennsylvania Press, 2001), 72. Debo esta referencia a uno de los evaluadores del artículo. Acerca del símil de las flores en referencia a la menstruación, vid. también Mišná «Niḍá» cap. 2 mišná 5; y Fonrobert, Menstrual Purity, 87-97; S. F. Koren, «Kabbalistic Physiology: Isaac the Blind, Nahmanides, and Moses de Leon on Menstruation», AJS Review 28 (2004), 317-339: 319, 325; y CABALlero NAVAS, «Palabras de rabinos», 303-310: 306.

${ }^{23}$ Sobre la impureza de la mujer menstruante se ha producido en las últimas décadas una bibliografía abundante; vid., por ejemplo, Fonrobert, Menstrual Purity, 27-29; y
} 
En el Źóhar hacadóš diǰeron que non hay tumá fuerte en el mundo como la tumá de_la niḍá que lugo que se acerca a_su lado le encona su cuerpo y su alma, ḥ"v [E. PAPO 1884: 30b-31a].

Papo critica a aquellos que piensan que las prohibiciones relativas a las menstruantes deben aplicarse únicamente a sus esposas. Le parece conveniente aclarar que la transgresión de esas leyes es muy grave cuando uno tiene relaciones con su mujer menstruante, pero con mucha mayor razón cuando las tiene con la mujer menstruante de su compañero:

Lo_que entienden el 'olam que el isur de niḍá es sólo con su mujer están muy yerados por raźón que con su mujer afilú es tan peśgado, kol šekén con mujer de su ḥaber [E. PAPO 1884: 31a].

En el siguiente párrafo el rabino hace una distinción entre el flujo de sangre menstrual y la hemorragia causada por hemorroides. Recomienda no fiarse de la opinión del médico, según la cual la sangre emitida por los genitales femeninos sería causada también por hemorroides. Para aclarar cualquier duda relacionada con la (im)pureza de la mujer, el rabino da a conocer que la emisión de flujo de la sangre proveniente de los genitales constituye una impureza:

Mujer que tiene vena de oro ${ }^{24}$ que le_viene sangre mipí hatabác at y le dijo un médico que tanbién la sangre que le_viene a esta mujer por el lugar de la 'ervá es de la vena de oro, non lo_creemos al médico y dita mujer es enconada [E. PAPO 1884: 31a].

Los rabinos han prescrito la abstinencia de las relaciones sexuales desde las 12 horas antes del comienzo de la menstruación. En el siguiente pasaje se dan ejemplos en los que el flujo de sangre puede aparecer a lo largo del día o de la noche ${ }^{25}$ :

Toda mujer que vino su tienpo de veer sangre, su marido se apartará de ella 12 horas, dehainu, si le uśa a_venir la sangre de diya se

H. Ner-DAvid, «Medieval Responsa Literature on Niddah: Perpetuations of Notions of Tumah», en Menstruation: A Cultural History, A. SHAIL / G. HowIE (eds.) (BasingstokeHampshire-New York: Palgrave Macmillan, 2005), 188-199.

${ }^{24}$ Se refiere a hemorroides. Se trata de una traducción literal del alemán Goldener Ader ('vena dorada, vena de oro').

${ }^{25}$ Sobre ese tema, vid., por ejemplo, Sultan, A Rose of the Valley, 35-41, 113, 191-205. 
apartará todo aquel diya, y si le_uśa a_venir de noche se apartará toda la noche [E. PAPO 1884: 31a].

Se da otro ejemplo en el que se explica cómo reaccionar cuando el flujo de la sangre menstrual aparece a lo largo de una comida que comparten marido y mujer:

Mujer que estaba comiendo con su marido de un plato siendo estaba linpia y betoj de la comida le_vino el dam nị̣ut es mutar de escapar de comer con ella. Siendo que enpezó la se 'ud' con heter, la puede escapar [E. PAPO 1884: 33b].

\section{SEPARACIÓN ENTRE HOMBRE Y MUJER DURANTE EL PERIODO DE IMPUREZA}

Papo había expuesto las leyes relativas al apartamiento menstrual entre hombre y mujer en dos libros suyos: Damésec Eli éźer: Yoré de á (Belgrado, 1865) y Damésec Eli éźer: Yoré de á (Jerusalén, 1884). La recopilación de las leyes es casi idéntica en ambos libros. La única diferencia consiste en que en el primero de ellos añade el siguiente pasaje didáctico y moralizador:

Y agora tú, mi seño' meldador hermośo, si patrón de alma hermośa tú y queres alcanzar a vejez y non seer malogrado a_la mancebez, mira de te acavidar muy bien cuando está nị̣á tu mujer y merecerás a źera' kašer [E. PAPO 1865: 68b].

Como ya se ha visto supra, uno debe estar «aparte de su mujer» durante el periodo de menstruación y los siete días seguidos hasta el momento en que la mujer se sumerge en un baño ritual. El contacto físico entre los cónyuges durante ese largo periodo aparece limitado, y la separación entre el hombre y la mujer está regulada por numerosas leyes ${ }^{26}$. Así, por ejemplo, está prohibido intercambiarse utensilios y debe controlarse el habla, hablando lo necesario y absteniéndose de tratar de cosas burlescas

\footnotetext{
${ }^{26}$ Vid., por ejemplo, KamsLer, «Hebrew Menstrual Taboos», 77-79; GreEnBERG, How to Run, 123-124; Sultan, A Rose of the Valley, 97-142; y T. Hartman / N. Marmon, «Lived Regulations, Systematic Attributions: Menstrual Separation and Ritual Immersion in the Experience of Orthodox Jewish Women», Gender and Society 18 (2004), 389-408: 394-395.
} 
y frívolas. Cada uno debe comer de su propio plato; el marido no debe comer ni beber de la misma vajilla que la mujer, aunque a la mujer se le permite beber de un vaso previamente usado por su marido. Está prohibido sentarse en la cama de la menstruante; el marido y la mujer deben dormir en camas separadas que no pueden tener contacto la una con la otra. La pareja tiene que tener cuidado de no sentarse juntos en una carroza o en una nave, excepto cuando se va de viaje, lo que se permite bajo la condición de que las ropas de ambos no se toquen. El marido no debe mirar a la cara a su mujer, y sería conveniente que ésta llevara durante ese tiempo un vestido especial para que los cónyuges recuerden que deben estar apartados y respetar las leyes prescritas.

1. Es que no pueden dar ni tomar de mano a mano [hb. $]^{27}$. El simán es niḍá, quere dećir ni_da ni toma ${ }^{28}$.

2. Non se pueden aronjar de mano a mano [hb.].

3. Non pueden haćer sehoc y calut roš [hb.].

4. Se acaviden de non hablar muncho salvo lo_que es hejréah davcá. El simán es ne'elamti dumiyá hehešeti ${ }^{29}$, rašé tebot, niḍa ${ }^{30}$ [hb.].

5. Se acaviden de non comer de un plato salvo cada uno comerá aparte. Y si non le puede ser de comer aparte, a_lo menos se acaviden de non meter todos dos las manos enjunto en el plato [hb.] (vején minhaguenu beTurquiya ${ }^{31}$ ).

6. Se acavide de non comer de la comida que le restó de ella. Ansí non beber de el vaśo que bebió ella [hb.]. Ansí se acavide de non beber agua del tas que bebió ella, enpero la mujer es mutar de beber de el vaśo de su marido [hb.].

7. Se acavide de non asentarse en la cama de su mujer niḍá. Y non quere dicho que non se_puede echar a_dormir non el marido en la cama de la mujer y non la mujer en la cama del marido [hb.].

\footnotetext{
${ }^{27}$ Marco de esta manera la omisión en mi edición de breves pasajes del texto en hebreo (en algunas ocasiones, se trata de referencias a fuentes; en otras de detalles del asunto tratado).

${ }^{28} \mathrm{El}$ autor ofrece a sus lectores una frase nemotécnica para recordar la ley de no dar ni tomar, proponiendo la palabra clave en hebreo niḍa y haciendo un juego de palabras en judeoespañol ni_da ni toma.

${ }^{29}$ Sal 39:2: 'enmudecí silencioso, callé sin decir palabra'.

${ }^{30}$ El rabino de nuevo hace uso de la palabra niḍá como clave nemotécnica.

${ }^{31} \mathrm{Hb}$. 'Y así [es] nuestra costumbre en Turquía'.
} 
8. Es asur de acercar las camas que_toquen una con otra [hb.].

9. Se acaviden a_non asentarsen en una caroz̧a o en una nave cuando se_van a_paseyar, enpero si se_van a_camino es mutar, aj bitnay que se acaviden que_non se toquen los vestidos uno con otro [hb.]

10. Se acavide de non mirar en su mujer vején ella non mire en su marido. Y hay quen que diće que ya puede mirar en su cara [hb.]

11. Se acavide la mujer a_tener vestido apropiados [sic] para su nidut, en_tal que se acodren todos dos que está niḍá [E. PAPO 1884: 30a-b].

Durante el tiempo que la mujer emite el flujo de sangre menstrual (en palabras de Papo, «en los días que vee sangre») y durante los días siguientes, cuando empieza a contar los días limpios («los días de la sefirá»), o los días con manchas de sangre («tanto que vido sangre tanto que vido kétem»), está prohibido realizar otras acciones y trabajos: la mujer no debe mezclar con agua las bebidas alcohólicas en un vaso y servírselo a continuación a su marido; no debe hacer la cama en su presencia; y tampoco puede echarle agua caliente para que se lave. Al mismo tiempo, al marido le está prohibido servir un vaso para su mujer; quitar suciedad o plumas de su vestido soplando; y encender una vela que esté en las manos de su mujer. Es interesante la última observación que realiza el rabino, según la cual, en contra de las normas mencionadas hasta aquí, el marido puede terminar de fumar la pipa de tabaco que había comenzado a fumar su mujer:

12. Todas las melajot que la mujer le haće a_su marido, la niḍáa le haće a_su marido afuera de templarle vaśo de vino y raquí y todo modo de cośa que enboracha que es asur. Enpero agua y resto de bebrajes es mutar [hb.].

13. Se acavide la mujer de non haćerle la cama delantre de él [hb.].

14. Es asur a_la mujer de echarle agua a_su marido para que se lave su cara, sus manos y sus pies, afi' que non toca en él kelal. Y afi' agua yelada es asur [hb.].

15. Como que la mujer es asur de templarle el vaśo a su marido, ansí el marido es asur de templar el vaśo a su mujer [hb.].

16. Se acavide de non asoplar el polvo o las plumas de el vestido de su mujer niḍá [hb.].

\footnotetext{
${ }^{32}$ Es decir, la mujer menstruante.
} 
17. Si la mujer tiene en su mano alguna candela, se acavide de non encender de su mano su marido [hb.].

18. Mujer niḍa que bebió ${ }^{33}$ media pipa de taḅaco puede su marido beber lo_que restó [hb.].

19. Todos estos acavidamientos cale que se acavide tanto en los días que vee sangre tanto en los días de la sefirá tanto que vido sangre tanto que vido kétem (mancha) [E. PAPO 1884: 30b].

En los manuales de Papo se detallan algunas de las leyes que deben aplicarse en casos especiales, por ejemplo, cuando el varón está enfermo y cuando está enferma su mujer menstruante:

20. Si el marido está ḥaćino y non hay a él quen que lo sierva otro que su mujer, es mutar a_la mujer de servir a_su marido afi' que está niḍá, aj bitnay que se acavide de non lavarle a_su marido su cara y sus manos y sus pies y de non adobarle su cama delantre de él [hb.].

Si el marido está haćino o abel o viejo y non su yéŝer se mayorga sobre él, le_puede su mujer tenplar a él vaśo, afi' que está niḍa [hb.].

Mujer niḍá y está hạacina es asur a_su marido de tocar en ella y davcá cuando el marido está haćino y ella sana, es mutar de servirlo por raźón que siendo el marido está haćino non su yéŝer se mayorga sobre él siendo está flaca su fuerza. Enpero cuando la mujer está hacína y él está sano hay de sospechar quizás si se mayorgará sobre él el yéŝer harác y verná a_cośa de pecado, ḥ"v, por esto es asur [hb.].

En tienpo que su mujer está niḍá y hacćina y non tiene quen que la sierva, lo obligamos a su marido que le tome una mujer para que la sierva. Enpero si non topa mujer o que está en civdad que non hay jidiós, a_la hora es mutar a_su marido para servirla afi' que es haćinura que non hay sekaná. Enpero se acavide de non lavarle su cara y sus manos y sus pies siendo son cośas de hịạa [hb.].

Mujer que está niḍa y está ḥaćina de haćinura que hay sekaná, a_la hora es mutar a_su marido de haćerle todo modo de cośa [E. PAPO 1884: 30b].

También en otras circunstancias límites las leyes de separación se hacen más livianas como, por ejemplo, cuando fallece la menstruante o su marido. Este párrafo concluye con una interesante crítica de una práctica popular, según la cual las mujeres no permiten que una mujer menstruan-

${ }^{33}$ Es decir, que fumó media pipa; calco del tc. tütün iç-. 
te se acerque a su marido fallecido. Con ello, Papo intenta enseñar a las mujeres acerca de la normativa correspondiente a tales ocasiones:

Mujer que está niḍá y se murió, b"m, es mutar a_su marido de acercarse cerca ella y tanbién llevarla a bet haquebarot. Vején mujer que está nị̣á y se murió su marido, b"m, puede acercarse cerca él. Y esto es pašut [...], que afilú en lo_que está hacíino su mujer niḍa lo puede topar, kol šekén cuando está muerto que es mutar. Ma siendo vide a_las našim źequenot que non dejan a_la niḍá que se acerque cerca de su marido, por esto lo escribo que sepan que es mutar gamur [E. PAPO 1865: 69a].

\section{CuentA DE SIETE DÍAS LIMPIOS E INSPECCIÓN}

En la literatura rabínica se describen muy detalladamente distintos tipos de manchas de sangre ${ }^{34}$, y en nuestro corpus encontramos la siguiente descripción:

12. Mancha de sangre que cuando pasaron el dedo sobre ella salió dita sangre, afi' que salió con pasar el dedo, es enconada [hb.]. Y non se_quere dicho si salió dita sangre mikóạ̣ que arasparon en ella con la uña a que la fregaron con los dedos y salió que es tumá, sobre esto cale acavidar a_las mujeres [E. PAPO 1884: 33a].

Se dan instrucciones para la participación de la mujer impura en los ritos de tránsito como, por ejemplo, cuando inmediatamente después del sangrado en el parto una mujer es madrina en la circuncisión de su hijo ${ }^{35}$ :

Niḍá.- Mujer parida que quere ser sandéquet de su hijo ${ }^{36}$ y el minhag es que la sandéquet toma a_la criyatura y lo lleva en la caśa que se haće la milá y se lo_da en mano del abí habén, tomará la parida al hijo en ${ }^{37}$ sus manos con 2 cojines y viene el abí habén y toma al

${ }^{34}$ Vid. Fonrobert, Menstrual Purity, 103-115; Sultan, A Rose of the Valley, 41-50, 89-93; y Fram, My Dear Daughter, 104.

${ }^{35}$ Sobre la ceremonia de la circuncisión y sus costumbres, vid., por ejemplo, E. RoMERo, El libro del buen retajar. Textos judeoespañoles de circuncisión (Madrid: CSIC, 1998).

${ }^{36}$ Escrito

${ }^{37}$ Escrito s. $^{3}$. 
hijo con el pirmer coǰín y el segundo cojín resta en mano de su mujer y se topa que non toca en su mujer niḍá kelal [E. PAPO 1884: 33a-b].

Después de concluido el periodo de menstruación -que normalmente dura cinco días- la mujer debe inspeccionarse detalladamente, y a partir del día siguiente está obligada a contar siete días limpios, también llamados 'blancos' (hb. lebanim). El cómputo o cuenta (hb. sefirá) de esos siete días es válido si en ellos no aparece ninguna mancha de sangre. Las instrucciones acerca de la cuenta de días y de la inspección íntima con un trapo de algodón o de lino introducido en la vagina durante ese periodo son muy precisas:

4. Mujer que vido sangre o mancha enconada -tanto que se ajuntó con su marido, tanto que non se ajuuntó- y afi' si non está su marido en la civdad, non puede enpezar a_contar los 7 diyas linpios hasta que non pasan 5 diyas con el diya que vido la sangre. Mašal, vido la sangre diya de alḥad, conta alḥad 1 , lunes 2 , martes 3 , miércoles 4 , jueveś 5 , y tadre de jueveś tomará un tavayol o trapo de algodón blando y se lo entrará dientro de aquel lugar ${ }^{38}$ muy bien entrado y antes de acšam lo sacará y lo mirará. Si estuvo linpio enpeza de día de viernes a_contar los 7 diyas linpios y contará viernes 1, šaḅat 2 , alhạad 3, lunes 4, martes 5, miércoles 6 , jueveś 7 , noche de viernes que es noche de 8 , a hora de acšam tomará tebilá y se alinpiyará para su marido [E. PAPO 1884: 31a-b].

Después de dejar de sangrar, la mujer debe inspeccionarse, y tras averiguar que está limpia, tiene que ponerse ropa y vestidos limpios y empezar a contar siete días. Si a lo largo de esos siete días aparece alguna mancha de sangre, la cuenta se anula y debe empezar a contar de nuevo a partir del día que ya no hay mancha alguna. Durante esos siete días es recomendable inspeccionarse diariamente dos veces, por la mañana y por la tarde, pero según la opinión expresada al final del siguiente párrafo es también suficiente una vez al día, o incluso sólo alguno de los siete días en caso de que no encontrara ningún rastro de sangre:

5. Mujer que se badcó tadre de jueveś asegún diǰimos y se_topó linpia, lugo se_vestirá camiśa linpia y mijnasáyim linpios que non

\footnotetext{
${ }^{38}$ Con ese eufemismo se refiere al órgano sexual femenino.
} 
haiga ninguna mancha en ellos. Que si_topara en algún diya de los 7 diyas linpios alguna mancha, afi' en el diya seteno, todo lo_que contó es nada, y en el diya que topó la sangre o la mancha, a_la tadre se badcará muy bien con trapo dientro de aquel lugar asegún dij̄imos. Y si se_topó linpia de el diya de amañana, enpezará a_contar otros 7 diyas linpios, siendo todos estos 7 diyas se_queren linpios sin ninguna sangre y sin ninguna mancha. Que por esto en cada diya de estos 7 linpios, cale que se badque a_ver si está linpia dos većes cada diya, una veź la mañana y una veź la tadre o a_lo menos se badcará una veź cada diya. Si non se badcó en todos los 7 diyas salvo una veź, tanto que se badcó en el diya pirmero de los 7 , tanto que se badcó en el diya de 7 o en algún diya de los de en-medio, siendo que ya se badcó una veź y ya se_topó linpia, muy bien le_contan estos 7 diyas y tomará tebilá la noche de 8 [E. PAPO 1884: 31b].

El rabino puntualiza acerca de situaciones especiales. Así, por ejemplo, cuando por honra de la fiesta sabática la mujer se viste ropa aseada y empieza a contar días limpios uno más tarde de lo debido, y Papo explica qué manera tiene de retomar esa cuenta de los siete días limpios después de haber descubierto mancha o flujo de sangre durante el periodo de la cuenta:

Mujer que le_vino su tienpo de vestirse paños en diya de šaḅat y non se vistió hasta diya de alhad a medio-diya y tomó tebilá al otro alhad a medio-diya, esta mujer cale que torne a_tomar tebilá diya de alḥad después de acšam [...].

6. Mujer que enpezó a_contar los 7 diyas linpios y en algún diya de estos 7 se topó alguna mancha o que_vido sangre mamáš, non cale que aspere ${ }^{39} \operatorname{los} 5$ diyas que dijimos ariba en din 4, salvo lugo enpeza a_contar los 7 linpios de muevo. Mašal, enpezó a_contar los 7 diyas linpios de alhad y diya de martes se topó que non estuvo linpia alhad y lunes y martes non se contan por nada y tadre de martes cerca acšam se_badcará con trapo entrado dientro de aquel lugar asegún dij̄imos en din 4, y si se_topó linpia enpezará a_contar otros 7 diyas linpios de diya de miércoles [E. PAPO 1884: 31b].

Papo testimonia en sus escritos algunos minhaguim y nos habla de la costumbre de lavarse en un baño público después de terminar de menstruar y antes de empezar a contar los días limpios. Si no hay posibilidad

\footnotetext{
${ }^{39}$ Escrito אספרי aspre.
} 
de acudir a un baño público la mujer puede lavarse en casa las partes más íntimas y cambiarse de ropa. También se explica que en casos especiales, por ejemplo, durante un viaje, las leyes de inspección se vuelven más livianas:

7. Minhag bueno es que la mujer en el diya que ya se_topó linpia, mašal, diya de alḥad, se escaparon los 5 diyas y se badcó diya de alḥad a_la tadre asegún diǰimos en din 4 y se_topó linpia que ya va a enpezar a_contar los 7 diyas linpios de diya de lunes, tadre de alhad se_van al baño y se_lavan y se_visten camiśa y mijnasáyim linpios. Enpero si non puede ir al baño se lavará en caśa, sólo en aquel lugar ya le aḅasta. Y en hora de apreto, como dećir, mujer que está por camino ni tiene camiśa ni tiene mijnasáyim para trocarse, muy bien puede contar los 7 diyas linpios sin lavarse kelal, salvo con badcarse sólo a_ver si está linpia, y la camiśa y los mijnasáyim que mire que estén linpios de todo modo de sangre y ya puede ser y sin que se_troque [E. PAPO 1884: 32a].

Para que no haya una interpretación equívoca de la ley expuesta anteriormente, se hace énfasis en diferenciar los cinco primeros días de la regla y los siete días limpios, sobre todo lo que concierne al sangrado o a las manchas de sangre:

8. Y sabréš que todo esto que dijimos que si se_topó sangre o mancha que todo lo_que contó es nada y cale que conte ${ }^{40}$ de muevo, esto es davcá en los 7 diyas linpios, enpero en los 5 diyas que dij̄imos ariba en din 4, afi' que vido sangre en todos los diyas, basta que a_la tadre de 5 se_topa linpia, a_la mañana enpeza lugo a_contar los 7 diyas linpios [E. PAPO 1884: 32a].

Se especifican algunos de los problemas médicos específicos relacionados con la matriz de las mujeres ancianas que supuestamente ya no menstrúan y se aconseja consultar al rabino local en caso de que aparezcan manchas de sangre:

9. Mujer que mehamat que le_caye la madre para aḅajo y cuando se apreta con la mano para entrarse la madre para ariba vee manchas de sangre, cale que demande al se' hajam siendo hay muchas diferencias de dinim asegún escribiremos [E. PAPO 1884: 32a].

\footnotetext{
${ }^{40}$ Escrito ponto.
} 
En la obra Damésec Eli 'éźer: Yoré de á (Jerusalén, 1884), dedicada en su mayor parte a las leyes relativas a las mujeres, hay un bloque importante de las leyes de pureza ritual con el título Dinim de novia que va entrar a_la hupá, que deben aplicarse a las novias que, antes de casarse, tienen también que contar siete días limpios e inspeccionarse ${ }^{41}$ :

10. Novia que le_diǰeron a ella si se_quere caśar y dijo que sí, tanto que seya grande, tanto que seya chica, cale que guadre 7 diyas linpios. Mašal, diya de alhad intimaron que va a acaśar dita novia diya de viernes y alhad non se conta nada, y enpezará a_contar de lunes: lunes 1 , martes 2 , miércoles 3 , jueves 4 , viernes 5 , šabat 6 , alḥad 7 , noche de lunes toma tebilá y se alinpiya para su novio. Y en estos 7 diyas linpios cale que se badque en cada diya a_ver si estuvo linpia asegún aviśimos ariba en din 5 esteso din es y aquí [E. PAPO 1884: 32b].

Antes de su boda, las novias mayores que ya han dejado de tener su menstruación y las jóvenes que, sin ser estériles, todavía no han tenido la primera, están también obligadas a inspeccionarse durante siete días antes de entrar en el baño ritual por inmersión:

Y afilú mujer vieja que hay tantos años que non vido ninguna sangre, si se_va a_caśar cale que guarde ditos 7 diyas que dij̄imos [hb.]. Y ansí muchacha de 22 años que non vido sangre kelal y la batcaron mujeres y vieron que non es aylonit mañera ${ }^{42}$ y se_va a_caśar, cale que guadre todos 7 diyas y tomará tebilá y dirá berajá tanbién asegún todo modo de mujer [E. PAPO 1884: 32b].

Este pasaje nos ofrece una mención de mujeres que inspeccionan a otras mujeres, probablemente expertas en ginecología práctica, y que son -al lado de rabinos y médicos- las más conocedoras de los cuerpos femeninos y de las prácticas realizadas exclusivamente por las mujeres ${ }^{43}$.

${ }^{41}$ Sobre las leyes especiales para la purificación de la novia, vid., por ejemplo, M. Molno, Usos y costumbres de los sefardies de Salónica (Madrid-Barcelona: CSIC, 1950), 22-25, 45; Sultan, A Rose of the Valley, 227-245; S. Weich-Shahak, La boda sefardí: Música, texto y contexto (Madrid: Alpuerto, 2007), 83-96; y Fram, My Dear Daugther, 129-130 y 208-210.

${ }^{42}$ La palabra hebrea aylonit ('estéril') y la judeoespañola mañera se yuxtaponen como sinónimos.

${ }^{43}$ Sobre las mujeres con saberes médicos vid., por ejemplo, CABALlero NAVAS, «Mujeres, cuerpos», 37-61: 49-55; EAD., «Medicine and Pharmacy», 249-259: 255; EAD., «Palabras de rabinos», 303-310: 304-306, 308-310. 
El siguiente pasaje nos revela otra práctica femenina que, a veces, discrepa de la normativa prescrita, pero que está admitida en casos de emergencia:

Novia.- Hay mujeres que uśan que afi' la novia non enpeza a_ contar los 7 diyas linpios hasta que non pasa 5 diyas de el diya que vido la sangre (asegún aviśimos ariba en din 4). Enpero en hora de apreto hay de ser matir a_la novia que lugo, asegún le destajó la sangre, que enpece a_contar los 7 diyas linpios. Mašal, tadre de alḥad se badcó y se topó linpia, enpeza lugo de lunes a_contar los 7 diyas y toma tebilá noche de lunes (asegún diǰmos ariba en din 4). Y ansí es lo mejor de haćer en tal que non entre la novia a_la ḥupá en lo_que está niḍa [E. PAPO 1884: 32b].

En la práctica ocurre que la boda se pospone por cualquier razón, lo que puede perjudicar la cuenta de los días, según se detalla en los siguientes párrafos:

11. Novia que intimaron por ella diya de alhad que viernes tiene de entrar a_la ḥupá, y la se' novia lugo de diya de lunes enpezó a_contar los 7 diyas linpios, y después por alguna sibá se enpujó la hupá que non puede ser viernes, todos los diyas que contó linpios non le aprovechan nada, y cuando tornarán y intimarán la hupá se_quere que conte otros 7 diyas linpios de muevo [hb.].

Y esto que dijimos que se_quere que torne a_contar otros 7 diyas linpios es en un ofen, que en la hora que se_dijo que non puede ser la ḥupá viernes non intimaron en aquella hora cuándo va a_ser la ḥupá. Enpero si lugo intimaron y dijeron que viernes non puede ser, que seya martes o miércoles, a_la hora non se_quere que torne a_contar otros 7 diyas linpios [E. PAPO 1884: 32b].

A todos los cambios de la fecha prevista para la celebración de la boda se añaden incluso más inconvenientes cuando los padres de los novios no viven en la misma ciudad y comunican sus decisiones a través de un emisario:

Novia que intimaron los nisuín después de Sukot y r"ḥ elul vino el padre del novio en la civdad de la novia y le_rogó la novia que sea la boda elul y el eshuegro respondió que por él ya está contente ma cale ir a caśa y demandará a_su mujer, y si querá mandará šalíạ̣ por la novia, y la novia enpezó lugo a_contar los 7 diyas linpios y ansí 
fue que intimaron de haćer lugo la boda elul y enỵiaron šalíạ por la novia, esta novia cale que enpece a_contar los 7 diyas linpios del diya que vino el šalíaḥ [E. PAPO 1884: 33a].

En caso de que la mujer hubiera recibido de su marido la carta de divorcio (hb. guet) y, después de un tiempo, el marido quisiera retomar las relaciones maritales con ella, la mujer estaría obligada a inspeccionarse y contar los siete días limpios antes de la boda:

Guerušá que le_dio guet su marido y tornó a tomarla ${ }^{44}$ cale que guadre ditos 7 diyas linpios que dijimos [hb.] [E. PAPO 1884: 32b].

\section{PURIFICACIÓN EN EL BAÑO RITUAL POR INMERSIÓN}

\subsection{Requisitos del micvé}

En Damésec Eli 'éźer: Yoré de 'á (Jerusalén, 1884, hs. 33b-35b) Papo aporta un nutrido capítulo dedicado exclusivamente a leyes, preceptos y prácticas relativos al baño ritual.

El baño por inmersión, en general, se realiza en un estanque construido exclusivamente para ese objetivo. El micvé es alimentado por agua natural corriente que sirve para la purificación ritual por inmersión. Para que éste sea lícito y pueda servir para su uso ritual debe cumplir una serie de reglas relativas a su construcción que regulan su tamaño, forma, profundidad, acceso de agua, etc. De los siguientes párrafos se entiende cuál es la importancia que tiene la cantidad de agua en él:

Tebilá de agua de luvia que estaba dientro del baño y cada día mancaba de la agua 2-3 dedos y vaćiaron la agua y non toparon ningún buraco, dita tebilá es kešerá siendo la agua que falta es del callentor del baño [E. PAPO 1884: 33b].

Tebilá que peśaron la agua y la toparon que manca de su ši ‘úr que es 259 oc' y $80 \mathrm{dr}$ ', las mujeres que sabemos cierto que cuando tomaron tebilá ya mancaban las aguas, cale que tornen a_tomar tebilá en micvé que está kašer como su din. Enpero las mujeres que

\footnotetext{
${ }^{44}$ Entiendo en el sentido de que vuelva a casarse con ella.
} 
tenemos safec si cuando tomaron tebilá estaba manco o estaba justo non cale que tornen a_tomar otra veź tebilá [E. PAPO 1884: 34b].

Se dan dos descripciones referentes a la construcción del baño ritual, la primera relativa al problema de llevar el agua corriente desde los tejados al baño, y la segunda dando explicaciones sobre los requisitos que éste tiene que cumplir para ser lícito:

Tebilá se_puede haćer con trayer agua de luvia de los tejados con oluques de palo o de fiero o de teneché [hb.], ma cale que seen ditos oluques asegún diremos [E. PAPO 1884: 35a].

Tebilá.- Quen que tomó chabro ${ }^{45}$ o bota y la entró dientro de la tiera y la hinchó de agua manante o de agua de luvia non puede tomar tebilá en ella siendo que tuvo nombre de kelí antes que la entre en la tiera. Enpero si non tuvo nombre de kelí antes ${ }^{46}$ que lo entre en la tiera, como dećir, que tomó dito chabro o dita bota y la aburacó el dip o de los lados junto al lado del dip ši úr que non reste dientro ningún modo de agua. Enpero si restó agua cual-sequer cośa dientro de dito kelí, non se_puede tomar tebilá dientro, siendo se_llama ayinda kelí, y dito buraco se_quere que seya grande ši úr que entran los dos dedos de la mano, el eŝḅa ' y el amá berévaḥ, y después que la entró dientro de la tiera de_cierto esta tebilá es kešerá, siendo que ya se baldó el nombre de kelí y tanbién que ya non resta dientro ningún modo de agua y después que ya entró dito kelí buracado dientro de la tiera, puede tapar dito buraco con cal y con pedricas y ansí puede meter dientro de dito buraco una caña [hb.]. Y ši 'úr de agua que cale que haiga dientro de dito kelí es 259 oc' y 80 dr' [E. PAPO 1884: 34b-35a].

Papo testimonia y critica una práctica curiosa según la cual las mujeres introducían una silla en el estanque de un baño ritual que era muy hondo para poder tocarla con los pies y evitar así el miedo a la profundidad:

Tebilá que está muy honda y se espantan las mujeres de aḅajar en ella, non pueden meter sía en la tebilá para pararsen en dita sía en la hora que toman tebilá [E. PAPO 1884: 35a].

${ }^{45}$ Sobre este vocablo vid. E. PAPO, «Slavic Influences on Bosnian Judeo-Spanish, as Reflected in the Literature of the 'Sephardic Circle'», en La memoria de Sefarad: Historia y cultura de los sefardíes, P. M. PIÑERo RAMírez (coord.) (Sevilla: Fundación Sevilla NODO, Fundación Machado, 2007), 267-286: 283.

${ }^{46}$ Escrito אגטיס agtes. 
Hay que tener en cuenta que el lavado ritual también puede hacerse en la naturaleza: en un manantial, fuente, río, riachuelo, etc. ${ }^{47}$; y según el autor, hasta en un balneario o termas:

Tebilá.- Las mujeres pueden tomar tebilá en las lij̄as [E. PAPO 1884: 34b].

\subsection{Preparativos para el lavado ritual}

En el siglo XIX la purificación ritual solía realizarse en los baños públicos, y así en la mayoría de las ciudades del Imperio otomano tenía lugar en los baños turcos donde ciertos días se reservaban para uso de judíos ${ }^{48}$.

Antes de inmersión ritual la mujer debe inspeccionarse por sí misma y, en la mayoría de los baños públicos, su limpieza está revisada por una mujer que asiste y ayuda en la inmersión ${ }^{49}$. Papo no ofrece ninguna noticia clarificadora al respecto, pero da las instrucciones para un baño ritual que se realiza en una ciudad donde no hay ninguna mujer judía que podría acudir como asistente en el lavado:

${ }^{47}$ Sobre distintos aspectos del baño ritual, vid., por ejemplo, S. S. SEREd / R. KAPLAN / S. COOPER, «Talking about Miqveh Parties, or Discourses of Gender, Hierarchy, and Social Control», en Women and Water, Wasserfall (ed.), 145-165; J. AlloucheBenayoun, «The Rites of Water for the Jewish Women of Algeria: Representations and Meanings», en Women and Water, WASSERFALL (ed.), 198-216; N. MARMON, «Reflections on Contemporary Miqveh Practice», en Women and Water, WASSERfALL (ed.), 232-254; I. E. Cicurel, «The Rabbinate versus Israeli (Jewish) Women: The Mikvah as a Contested Domain», Nashim: A Journal of Jewish Women's Studies and Gender Issues 3 (2000), 164-190; Sultan, A Rose of the Valley, 145-178; E. Horowitz, «Between Cleanliness and Godliness: Aspects of Jewish Bathing in Medieval and Early Modern Times», en Tov Elem: Memory, Community and Gender in Medieval and Early Modern Jewish Societies. Essays in Honor of Robert Bonfil, E. Baumgarten / A. Raz-Krakotzkin / R. Weinstein (eds.) (Jerusalem: The Mandel Institute for Jewish Studies, The Hebrew University of Jerusalem / The Bialik Institute, 2011), 29-54; entre otros.

${ }^{48} \mathrm{Al}$ respecto vid., por ejemplo, Weich-SHAHAK, La boda sefardí, 83.

${ }^{49}$ En hebreo es llamada balanit ('camarera de un establecimiento de baños'); al respecto, vid. Sered / KAPLAN / CoOPER, «Talking about Miqveh Parties», 145-165; y Cicurel, «The Rabbinate versus Israeli», 164-190: 185-186. 
Tebilá.- Reubén que está con su mujer en una civdad y non hay más ningún jiidió cuando la mujer toma tebilá, puede el marido verla deśnuda y mirar cómo toma tebilá que la tapen las aguas todo su cuerpo, y tanbién puede su marido ayudarla con sus manos a entrarle todo su cuerpo y su cabeza que estén dientro de la agua, aj bitnay que se acavide de antes a mojarse las manos por_que non sea ḥaŝiŝá [E. PAPO 1884: 35a].

Es de suma importancia el aseo individual antes de entrar al baño ritual. Bajo el epígrafe Dinim de cośas que son ḥaŝiŝá para tebilá se explican cuáles pueden ser los obstáculos que pueden invalidar un baño ritual como, por ejemplo, anillos, pendientes, pulseras, dientes picados, mocos, etc.:

Mujer que tomó tebilá con aníos: si estuvieron apretados non le aprovecha la tebilá, enpero si estuvieron ${ }^{50}$ flojos le aprovecha la tebilá [hb.]. Enỵeźamos de aquí que cale que se acaviden muy bien las mujeres de non tomar tebilá, non con ningunos aníos, non con orejales, non con manías. Y si tomó tebilá con alguno de estos, cale que demande algún hajam y que le amostre asegún están ditas cośas, si están apretados o están flojos, y el se' hajam le_dirá si le aprestó la tebilá o se_quere otra tebilá. Y si non hay a_quen demandar, lo mejor es que se saque los aníos o las manías o los orejales y que torne otra veź a_tomar tebilá.

Ḥaŝîsá.- Mujeres que tienen dientes de plata o de güeso non es haŝîsá para tebilá, enpero si tienen algún diente buracado y vino el médico y se lo tapó para que non le entre el aire, es haŝisáá para tebilá [hb.].

Mujer que teniya holi en su tripa y le hićieron los médicos ciertos palos y se los entraron dientro de otó macom ${ }^{51}$ y non se vee de afuera kelal, non es hạasîsá para tebilá. Y ansí mocos si están dientro de la nariź que non se veen non es hâsîisá, enpero si los mocos salieron un poco para afuera cale que se acavide de sacarlos por_que non seya ḥaŝisáá [E. PAPO 1884: 33b-34a].

Relativo a la higiene personal se menciona en dos ocasiones la limpieza de los dientes, sobre todo cuando con anterioridad al baño ritual se consume carne:

Niḍá.- Mujer que le acaeció su tebilá en noche de alḥad es mutéret de comer carne en šaḅat, aj bitnay que se acavide antes de tomar

\footnotetext{
${ }^{50}$ Escrito אוסטוב'יירון ostuvieron.

${ }^{51} \mathrm{Hb}$. 'aquel lugar', se refiere al órgano sexual femenino. Vid. nota 38.
} 
tebilá de escarbarse muy bien sus dientes [E. PAPO 1872-74: 201] ${ }^{52}$.

Se alude a dos métodos distintos de depilación de las partes íntimas antes de la inmersión ritual, uno parcial que se consigue usando una tijera, y otro total, mediante depilación usando un preparado. En este caso, el rabino ofrece como modelo a seguir las prácticas llevadas a cabo por mujeres y no la normativa rabínica, lo que añade valor e importancia al conocimiento de usos y costumbres femeninos relacionados con la observancia de las leyes de pureza en distintos lugares y épocas:

Tebilá.-Si tomó tebil' y se_cortó los cabellos de la 'ervá con tijera y non se untó droga por sacar el cabeo por entero asegún es el minhag de las mujeres, el din es que si ya se ajuntó con su marido, non cale que torne a_tomar tebilá, y si non se ajuntó con su marido cale que se saque su cabeo con droga mikol vajol asegún el minhag y que torne y que tome tebilá [E. PAPO 1884: 34a].

Son de especial interés las prácticas relacionadas con la higiene, y que el rabino considera de poca importancia como, por ejemplo, el siguiente uso popular según el cual las mujeres lavaban toda la ropa manchada con la sangre menstrual antes de la inmersión. Este uso nos muestra una actitud que podían tener algunas mujeres en el proceso de purificación, queriendo eliminar todos los rastros de la sangre menstrual también en la ropa antes de entrar al micvé:

Tebilá.- Lo_que uśan algunas mujeres para lavar todo modo de paño que hay en él sangre o mancha antes de tomar tebilá non hay de escatimar en esto kelal [E. PAPO 1884: 35b].

A pesar de que la sangre menstrual ha sido considerada tradicionalmente como nociva, se alude a un remedio popular (hb. segulá) ${ }^{53}$, según el cual una prenda manchada con la sangre menstrual tiene un efecto positivo ya que ayuda a apagar y alejar el fuego:

${ }^{52}$ Una formulación parecida encontramos en Damésec Eli 'éźer: Yoré de á (Jerusalén, 1884: 35a): «Mujer que se olvidó y comió carne en el diya que va a ir a tebilá puede tomar tebilá aj bitnay que se acavide de escarbarse sus dientes muy bien».

${ }^{53}$ Por ejemplo, en el prefacio a A. ZAKAI, Segulot y tefilot (México: Jerusalem de México, 2001) se explica que «en su sentido popular, la palabra segulá generalmente se refiere a palabras o actos específicos cuyo propósito es de algún modo contribuir al remedio o la curación de algún problema en el cuerpo o en el alma de la persona». El autor distingue las segulot que se plasman en rezos de las que, en esencia, son actos que tienen un fundamento médico olvidado con el paso del tiempo. 
Segulá maravillośa para amatar el fuego: tomarán camiśa de mujer que hay en ella sangre de niḍá y la pornán sobre la caśa que enfrente del fuego; y ya lo prebaron y vieron maravilla, que lugo se alejó el fuego [E. PAPO 1872-74: 57].

\subsection{El tiempo de la inmersión}

Según ya se ha dicho, las mujeres casadas tras (habitualmente cinco) días del sangrado menstrual seguidos de siete días limpios consecutivos sin sangrar, deben limpiarse minuciosamente a sí mismas en el baño o ducha habitual antes de realizar el baño ritual por inmersión, por medio del cual alcanzan de nuevo estado de pureza. Tras la inmersión ritual al final de los días de su purificación termina el periodo de abstinencia de relaciones sexuales y la pareja puede reanudarlas. En general, la mujer puede realizar el baño ritual (hb. tebilá) el séptimo día por la noche o el octavo día por la mañana. En las obras de Papo -originario de Sarajevo, la capital de la Bosnia otomana- encontramos varios ejemplos en los que el autor fija el tiempo de los rituales judíos teniendo en cuenta el horario habitual de las oraciones musulmanas. Así, por ejemplo, en relación a la plegaria que se pronuncia a la puesta del sol:

Tebilá en lugar que hay ones, como dećir, que se espanta de tomar tebilá en la noche mehamat del friyo o del miedo de ladrones o que tiene muchos većinos o que tiene hijos grandes en caśa y se le_va a_saber su tebilá, puede tomar tebilá en el día de 8 de tenprano de día y venir a_su caśa de tenprano de día para que non se le_sepa que fue a tebilá, ma davcá en el día de 8, enpero en día de 7 se_quere davcá de noche después de acšam namaźí tomar tebilá, enpero día de 7 tomar tebilá de tenprano de día que sepan que es isur gamur, que ansí cale que se acaviden muy bien siendo hay isur de karet [E. PAPO 1884: 33b].

Papo especifica que antes de casarse, la novia debe bañarse ritualmente el día octavo:

Tebilá.- La novia puede tomar tebilá en el diya de 8, enpero non puede tomar tebilá en diya de 7 [E. PAPO 1884: 34b]. 
Asimismo, las parturientas están obligadas a bañarse ritualmente, en general, siete días después de parir a un hijo y catorce días después de parir a una hija. No obstante, Papo les aconseja sumergirse después de siete días limpios tras la hemorragia causada por el parto ${ }^{54}$ :

Muj̀eres paridas que uśan a asperar 40 diyas cuando paren hijo y 65 diyas cuando paren hija, que sepan que están yeradas, salvo basta que ya le cortó la sangre, conta los diyas linpios (asegún aviśimos ariba din 4) y toma tebilá y se ajunta con su marido [E. PAPO 1884: 35b].

Según las palabras del rabino es preceptivo tener relaciones sexuales la misma noche después de la purificación en el baño ritual:

Ŝeni'ut.- [...] es hayab ajuntarse con su mujer en la noche de_la tebilá y en la noche que_va a_salir a camino. Y_si vee que_su mujer lo deśea y_se afeita para que dé sus ojos en ella es ḥayab de vis̀itarla y esto es el 'icar de la miŝvá de 'oná ${ }^{55}$ y tanbién merece a_tener hijos nebonim y hermośos [E. PAPO 1862: 181a].

La mujer siempre debe lavarse ritualmente a su debido tiempo para purificarse, incluso cuando no es posible cumplir el precepto de tener relaciones sexuales con su marido después de la inmersión ritual. Se da el ejemplo de cuando el marido no está disponible porque está de viaje, y también se nos informa de una práctica popular, según la cual las mujeres suelen vestir en esa ocasión una prenda que pertenece a su marido:

Mujer niḍá que non tiene a_su marido en la civdad es miŝvá a ella que tome tebilá en su tienpo, afilú que non está su marido en la civdad siendo es asur a_la mujer que_se pare con su tumá [hb.]. Y lo_que uśan algunas mujeres que cuando toman tebilá y non pueden estar con sus maridos que se visten sobre ellas algún vestido de sus maridos, esto es minhag de 'amé haarê̂ [E. PAPO 1865: 68b] ${ }^{56}$.

${ }^{54}$ Vid. P. Hidiroglou, Les rites de naissance dans le judaïsme (Paris: Les Belles Lettres, 1997), 227; Fram, My Dear Daughter, 125-127.

${ }^{55}$ Según la halajá, las obligaciones conyugales que tiene que cumplir el hombre con su mujer. Vid., por ejemplo, HARTMAN / MARMON, «Lived Regulations», 389-408: 402-404.

${ }^{56}$ Casi la misma formulación se repite en el libro Damésec Eliéźer: Yoré de á (Jerusalén, 1884: 35b): «Mujerer niḍá que non tiene a_su marido en la civdad es miŝvá a ella que tome tebilá en su tienpo, afi' que non está su marido en la civdad siendo es asur a_la mujer que se esté con su tumá [hb.]. Y lo_que uśan algunas mujeres que cuando toman tebilá y non pueden estar con sus maridos que se visten algún vestido de sus maridos esto es minhag de 'amé haaraŝot». 
La siguiente noticia contiene la regañina que el rabino dirige a algunas suegras que, por cualquier motivo, no han aconsejado a sus nueras a acudir al baño ritual en el momento adecuado:

[...] cuánto yeran las mujeres que se_devedan y non van a tebilá en su tienpo; y ansí, cuánto yeran las esḥuegras que devedan a_sus nueras que non vayan a tebilá en su tienpo por achaque de cual-sequer cośa. Non sea hecho como esto en Yisrael, salvo se acaviden que non pase de su tienpo bešum ofen šeḅa'olam [E. PAPO 1872-74: 127].

Además, y como hemos señalado con anterioridad, si se descubre que un lavado ritual no se ha realizado bajo las leyes y condiciones prescritas, se considera inválido y hay que repetirlo ${ }^{57}$, como nos enseña el siguiente relato breve:

Ma'asé en una mujer de un hajam que vino su mujer de la tebilá y ayinda estaba el sol en punta de los árboles y le_demandó a MoHaRa"M ${ }^{58}$ Amarillo y [éste] le_dijo que cuando es noche cale que torne otra veź a_tomar tebilá [E. PAPO 1884: 35b].

\subsection{El lavado ritual y las festividades}

Es especialmente importante que las mujeres sepan cuáles son las reglas relativas al tiempo de inmersión ritual, cuando ésta, según la cuenta de días limpios, cae en alguna de las festividades. Papo critica a las mujeres que en vez de acudir al baño ritual el jueves por la noche, esperan hasta el viernes por la noche cuando empieza šaḅat, el día más importante del calendario judío, ya que les parece mejor bañarse ritualmente en honor de esta festividad:

Tebilá que le vino su tienpo en noche de viernes hay muchas mujeres que les parece que mejor es dejar la tebilá hasta noche de šaḅat por kabod de šaḅat se haće de_menester de darles a_saber que

${ }^{57}$ Sobre ese tema, vid., por ejemplo, S. J. D. CoHEn, «Purity, Piety, and Polemic: Medieval Rabbinic Denunciations of "Incorrect" Purification Practices», en Women and Water, WASSERFALL (ed.), 82-100.

${ }^{58}$ Sigla de Morenu HaRab Riḅí Moše 'nuestro maestro, el rabino Mošé', en referencia a R. Hayim Mošé Amarillo (Salónica, 1695-1748). 
están muy yeradas y non haćen bueno a detardar la tebilá salvo que tomen tebilá en noche de viernes [E. PAPO 1884: 35b].

La inmersión realizada a su tiempo el viernes por la noche es de mucha importancia y, en parte, responsabilidad de las mujeres ya que ayuda a cumplir el precepto de procrear durante el día santo según se aclara en el siguiente pasaje:

Tebilá.- Mujer que le_vino tienpo de su tebilá en noche de šaḅat y tiene a_su ${ }^{59}$ marido en la civdad, es miŝvá raḅá que tome tebilá, afi' en noche de šaḅat en tal que non balde a_su marido de periyá urbiyá; y mujer que non toma tebilá lugo en su tienpo que sepa que es pecado, siendo haće baldar a_su marido de periyá urbiyá y lo haće pecar que venga lidé querí y źera' lebatalá [E. PAPO 1872-74: 126-127].

Se critica a las mujeres que realizan el lavado ritual antes de la puesta de sol al comienzo del šaḅat para poder llegar a tiempo a casa y encender las velas. Según el consejo del rabino, en este caso la mujer debe ir al baño ritual después de la puesta del sol y el marido tiene que ocuparse de encender a tiempo las velas en casa y pronunciar la bendición correspondiente:

Tebilá.- Hay mujeres que cuando les viene ${ }^{60}$ tienpo de su tebilá en noche de šaḅat toman tebilá de tenprano en tal de alcanzar a ir a_caśa y encender la candela de šaḅat, vaday que es ḥasidut de locura, salvo ella cale que tome tebilá cuando es noche y la candela que la encienda su marido y que diga berajá tanbién [E. PAPO 1884: 35b].

Se menciona otro caso cuando, a causa de sus maridos, las mujeres adelantan su inmersión ritual y no esperan hasta la noche según dicta la norma:

Tanbién hay mujeres que les viene su tienpo de ir a tebilá y, dićiendo 'arbit tenprano, se espanta de su marido que non se le arabiye que se detardó, vienen a_tomar tebilá antes de acšam, ašer 'a"k «yejalquel debarav» bedérej emŝa'í šalem ${ }^{61}$ [E. PAPO 1872-74: 249].

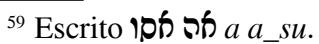

${ }^{60}$ Escrito ב"יתי

${ }^{61} \mathrm{Hb}$. '«gobierne sus cosas» [Sal 112:5] en el más absoluto término medio', (es decir, que arregle sus asuntos con justicia). 
Asimismo se da a entender que en caso de que el lavado por inmersión caiga en la festividad de Yom Kipur, la mujer no puede adelantarlo y realizarlo un día antes, la víspera de la fiesta:

Tebilá que le_vino su tienpo en día de Kipur non puede tomar tebilá en 'éreb Kipur para seer aparejada para su marido para noche de moŝé Yom hakipurim [E. PAPO 1884: 33b].

Sin embargo, si el lavado ritual cayera en una festividad de Tišcá beab que resultara ser šaḅat, y por ello se tuviera que celebrar el día siguiente (e.d., domingo), la mujer podría lavarse en el baño ritual el viernes por la noche al comienzo del šaḅat:

Niḍa que acaeció la noche de_su tebilá en noche de Tiš á beab que acaeció en šaḅat y se enpujó para día de alḥad puede tomar tebilá en noche de šabat y ajuntarse con marido [E. PAPO 1865: 69a] ${ }^{62}$.

Asimismo, se detallan las normas para la finalización de la festividad de Tišcá beab, un día de ayuno, cuando antes de entrar en el baño ritual se puede beber té o café pero no se debe comer hasta después de realizar la inmersión:

Tebilá que le_vino su tienpo en la noche que salió Tiš ‘á beab [hb.], dita mujer puede beber chay y cavé afi' con güevo que lo llaman batulín, enpero comer cale que aspere hasta después de la tebilá [hb.]. Y dita mujer se lavará ${ }^{63}$ y se_peñará en 'éreb T"b y en noche de moŝé T"b tornará a lavarse y a peñarse segunda veź [E. PAPO 1884: $35 b]^{64}$.

En su libro Damésec Eli ézér: Yoré de 'á (Belgrado, 1865), manual de normas y costumbres relativas a la muerte, Papo también recopila las leyes acerca del baño ritual en los días de duelo, cuando está prohibido lavarse y tener relaciones sexuales:

${ }^{62}$ Una versión casi idéntica aparece en Damésec Eli éźer: Yoré de’ á (Jerusalén, 1884: 35b): «Tebilá que le_vino su tienpo en noche de T"b que acayeció en šaḅat y se enpujó para alhad puede tomar tebilá en noche de šaḅat y ajuntarse con su marido».

${ }^{63}$ Escrito lavrá.

${ }^{64}$ Una versión menos completa de estas normas aparece ya en Damésec Eli éźer: Yoré de 'á (Belgrado, 1865: 69a): «Niḍa que acaeció la noche de su tebilá en moŝé Tiš á beab se lavará y se peñará en 'éreb Tišcá beab y en noche de moŝé Tišcá beab tornará a lavarse y a peñarse otra veź». 
Niḍá que se aparejó a ella el tienpo de su tebilá en los días de_su abelut non puede tomar tebilá siendo es sin demenester que es asurá en tašmíš. Enpero si_su marido está abel puede tomar tebilá para poder tocarse con su marido, enpero tašmíš es asur [E. PAPO 1865: 69a].

El rabino da instrucciones sobre la higiene y cambio de ropa durante esos días:

Niḍa que se quere mudar en los días de su abelut se lavará sólo en aquel lugar y las piernas con agua callente o yelada y se vestirá camiśa limpia, enpero non blanca mamáš [hb.] [E. PAPO 1865: 69a].

Se da una explicación también acerca del tiempo y modo de aseo del pelo y las uñas cuando el sexto día de los siete de duelo cae en viernes y debe entrar el sábado por la noche al micvé:

Niḍá que le acaeció la noche de su tebilá en noche de alhad y día de viernes es el día ses̀eno de su abelut, día de viernes a_la tadre se peñará su cabeza en caśa y en noche de alḥad antes de tomar tebilá tornará otra veź a peñarse, enpero las uñas non se puede cortar en día de viernes, salvo en noche de alḥad davcá. Y si le puede ser noche de alhad de peñarse muy bien, como dećir, que está cerca del merḥás y non tiene ningún miedo, a_la hora non se peñará en día de viernes kelal. Enpero si tiene algún ones que non se puede peñar muy bien en noche de alhad, a_la hora se puede peñar en día de viernes y tanbién se peñará en noche de alhad otra veź asegún diǰimos [E. PAPO 1865: 69a] ${ }^{65}$.

\section{A MODO DE CONCLUSIÓN}

El corpus de textos estudiados muestra que, a mediados del siglo XIX, los rabinos sefardíes continuaban transmitiendo a sus lectores una educación religioso-cultural del judaísmo con valores tradicionales mediante una literatura halájica popular que habían venido produciendo en lengua vernácula desde antiguo.

${ }^{65}$ Papo trata el mismo asunto en Séfer Méšec betí (Sarajevo, 1872-74: 321): «Niḍa que le acayeció la noche de su tebilá en noche de alhad y día de viernes es el día ses̀eno de su abelut, se puede ir al baño y peñarse y cortarse las uñas en día de viernes para tomar tebilá noche de alhad»; y remite a este párrafo en su libro Damésec Eli ézéer: Yoré de 'á (Jerusalén, 1884: 35b): «Tebilá que le vino su tienpo en diya de su abelut y ansí si le_vino su tienpo en noche de alḥad y diya de viernes ayinda está en el diya de 6 de su abelut (mira bsh"c Dms"E bediné Abelut bediné Niḍá y toparás todos sus dinim cómo cale haćer)». 
Acerca de la fortuna de esos manuales en el seno de las comunidades sefardíes de Bosnia dan cuenta dos noticias de la prensa judía. En el periódico Jevrejski Glas ('La Voz Judía'), publicado en Sarajevo entre los años 1928-1941 ${ }^{66}$, Maestro ${ }^{67}$ comenta que el rabino Eli'éźer Papo de Sarajevo era muy popular entre sus feligreses y que sus obras religiosas eran leídas por un público muy amplio. En otro artículo suyo, este mismo autor ${ }^{68}$ testimonia que la obra Damésec Eli éźer: Yoré de á (Belgrado, 1865), una recopilación de normas y costumbres relativas a la muerte, era especialmente popular hasta la Primera Guerra Mundial: muchos judíos [bosnios] tomaban de ella consejo y consuelo, leyéndola durante los días de duelo por las personas fallecidas.

No sabemos nada acerca de la recepción de la última obra judeoespañola de Papo, que lleva el mismo título que la que se menciona supra, Damésec Eli éźer: Yoré de 'á, publicada en Jerusalén en 1884. El propio autor cuenta que uno de los motivos para escribirla había sido transmitir a las mujeres las oraciones y leyes que debían conocer. En ese libro también alaba a las mujeres que saben «meldar en ladino» ya que de esa manera pueden leerlo y enseñar sus contenidos a otras mujeres sefardíes analfabetas ${ }^{69}$. Con todo no podemos saber cuál fue la verdadera recepción de las leyes de pureza entre sus lectores masculinos y femeninos. ¿Cuántas mujeres hubieran podido leer esas leyes por sí mismas? ¿Cuántas las conocieron a través de las lecturas e interpretaciones hechas por sus lectores masculinos o por otras mujeres?

Lo único que puede constatarse es el hecho de que también en la última obra mencionada, publicada en Jerusalén, el ambiente otomano aparece reflejado en la misma medida que en sus tres obras sefardíes aparecidas en los Balcanes, arrojando luz sobre la cultura material, costumbres religiosas, aspectos de la vida de otros pueblos, etc. El material expuesto nos habla, marginalmente, acerca de la posición que han tenido esos textos en un espacio religioso-cultural complejo y durante una época de

${ }^{66} \mathrm{~K}$. VIDAKović, Kultura španskih Jevreja na jugoslovenskom tlu: XVI-XX vek (Sarajevo: Svjetlost, $1990^{2}$ ), 60, 72-98.

${ }^{67}$ MaEstro, «Prilog», 2-3: 2.

${ }^{68}$ No he podido consultar directamente el artículo de J. MAESTRO «Šta su čitali naši stari» ['¿Qué leían nuestros antepasados?'], Jevrejski Glas 14/14 (1936), cuyas noticias y cita textual tomo de LeBL, Jevrejske knjige, 103.

${ }^{69}$ ŠMID, «Yoré de 'á». 
grandes cambios. Por otra parte, los textos nos ubican plenamente en el seno de una minoría étnico-religiosa del Imperio otomano y nos muestran sus particularidades: la observancia de las leyes de pureza ritual son una importante seña de identidad que diferencia a las mujeres judías de las de otras culturas religiosas.

Los escritos rabínicos comentados nos revelan una serie de detalles acerca de la vida más intima de la mujer sefardí. En su mayoría, se trata de materiales halájicos o normativos acerca de la impureza causada por la menstruación y otros flujos uterinos, establecidos por los rabinos y válidos para todas las épocas. No obstante, en el caso de las guías prácticas de Papo, revelan asimismo una serie de usos, costumbres y prácticas populares y locales que se llevaban a cabo por familias judías de la segunda mitad del siglo XIX.

Los comentarios, críticas y alabanzas que lanza el rabino acerca de los usos realizados por las mujeres son muy sugerentes. Sería indispensable conocer la otra cara de la moneda: el dominio y la autonomía que han tenido las mujeres a la hora de poner en práctica la normativa de pureza ritual. Sólo de ese modo podríamos completar nuestros conocimientos acerca de esa temática y responder cuestiones cuyas respuestas no están presentes en los textos rabínicos. ¿Qué opinaban las mujeres sobre los escritos del rabino? ¿Qué utilidad y valor tenían esos textos para las mujeres? ¿Qué opinaban ellas sobre sus comentarios acerca de sus propias prácticas y costumbres? ¿Se veían identificadas con ellas? ¿Discrepaban con la norma impuesta? ¿Qué significado tenía para ellas la observancia de esas leyes? 
Glosario

abel 'el que está de luto, de duelo' (hb. לאכ)

abelut 'luto, duelo' (hb. אלוס)

abí habén 'padre del niño (que participa en la circuncisión)' (hb. אדי הבאן)

aburacar 'agujerear, horadar'

acavidado 'precavido'

acavidamientos 'cuidados'

acavidar 'advertir', $\sim$ se 'cuidarse, tener cuidado'

acšam 'puesta del sol' (sc. àkšam, àhšam, tc. akşam, ahşam), namaźí 'bendición musulmana que se pronuncia a la puesta del sol' (tc. akşam namazl)

adam vid. ben

adobar 'arreglar, preparar'

afilú, abrev. afi' 'incluso' (hb. אפילו)

aj 'pero' (hb. אמ')

'a"k vid. ašer

alhạad 'domingo'

amá 'dedo medio' (hb. אמה)

amatar 'apagar'

'amé haareŝ, 'amé haaraŝot 'ignorantes' (hb. עממי הארץ, עמי האלאות)

aparejada: seer 'estar dispuesta a, preparada para'

aparejar 'llegar, tocar'

aprestar 'servir; valer'

'arbit 'oración de la noche' (hb. עלבית)

aronĵar 'arrojar'

ašer 'a"k abrev. de ašer 'al ken 'por tanto, por lo que, según eso' (hb. lit. 'que

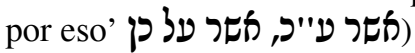

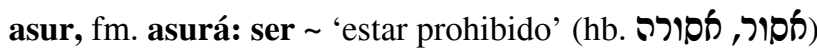

ayinda 'todavía'

aylonit 'estéril' (hb. איילוקית)

b'av"h sigla de ba 'avonot harabim 'por los muchos pecados' (hb. כעו"ה, בעונות (הרבים)

badcar(se), batcar 'inspeccionar(se), examinar(se)' (hb. קדב badac) 
baḥurim 'jóvenes' (hb. בסורים)

baldar 'abolir; inutilizar, impedir'

batcar vid. badcar

batulín: yema de huevo batida con azúcar $(¿ ?)$

beab vid. Tišcá

beber tb. 'fumar' (tc. tütün iç- 'beber'): vid. nota 33.

bediné 'en los preceptos de o relativos a' (hb. בדיפ)

ben adam 'persona, hombre' (hb. lit. 'hijo de hombre' בצדיפרן)

berajá ‘bendición' (hb. בכלכה)

berévah 'generosamente' (hb. ברכיכ)

bešum ofen šeba'olam 'jamás de los jamases' (hb. lit. 'de ninguna manera en el mundo’ בשוס אופן שבעולם): vid. ofen

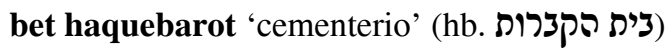

betoj 'dentro de' (hb. בכתוך)

bitnay (que) 'a condición de (que)' (hb. בתנמאנ)

b"m siglas de bar minán 'Dios nos libre' (hb. בצמתמ, בר מיכן)

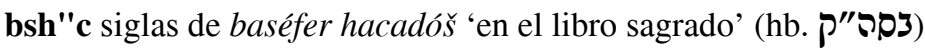

buracado 'agujereado; picado'

buraco 'agujero, hueco'

caler 'ser necesario u obligado, convenir'

calut roš 'frivolidad, irreflexión' (hb. lit. 'ligereza de cabeza' קלות כמש)

cavé 'café' (sc. kahva, kàfa, kàva, tc. kahve)

caynac 'fuente, manantial' (sc. kàjnak, tc. kaynak)

chabro ‘cántaro' (sc. čàbar): vid nota 45.

chay 'té' (sc. čäj, tc. çay)

c"v siglas de cal vahómer 'con tanta más razón, a fortiori' (hb. ק"ז, קל ומומר)

dam: niḍut 'sangre menstrual' (hb. דס פידות)

davcá 'precisamente, sólo, exclusivamente' (hb. דוקא)

dehainu 'es decir, o sea, así pues' (hb. דהייע)

destajar 'dejar, parar (de)'

devedar, se 'retraer(se), abstener(se), no hacer algo'

din, pl. dinim 'norma(s), precepto(s)' (hb. דין, דינים)

dip 'fondo' (tc. dip) 
Dms"E siglas de Damésec Eli 'éźer 'damasceno Eliézer' (hb. דמש"א)

dr' abrev. de drama: cierta medida de peso (ngr. $\delta \rho \alpha ́ \mu l$, sc. dram, tc. dirhem 'peso; moneda')

enconado 'impuro'

enconar 'impurificar'

enpujar 'trasladar'

entrar 'hacer entrar, meter'

enỵeźar 'aprender; enseñar'

elul: duodécimo y último mes del año judío que tiene veintinueve días y cuyo comienzo oscila entre el 8 de agosto y el 6 de septiembre, y por preceder a los días penitenciales de tišrí, es mes de recogimiento y devoción (hb. מאל (אלול) 'éreb: Kipur 'víspera de Día de la expiación' (hb. עכלב כפוכ); Tišcá beab, T"b 'víspera 9 del mes de ab' (hb. ערב תשעה באדב): vid. Kipur, Tiš‘á

'ervá 'órgano sexual femenino' (hb. ערוה)

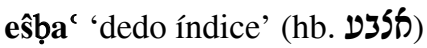

escapar 'terminar'

escatimar 'prestar especial atención, ser muy cuidadoso'

esḥuegro, esḥuegra 'suegro(a)'

esteso 'mismo, igual, idéntico' (it. stesso)

fiero 'hierro'

gamur vid. mutar

guerušá 'divorciada' (hb. גרושה)

guet '(carta de) divorcio' (hb. Dג)

haaraŝot, haarê̂ vid. 'amé

haber 'amigo, compañero' (hb. סכבר)

hacadóš 'el Santo' (hb. הקדוש)

haćino 'enfermo'

haćinura 'enfermedad'

hajajam, pl. hajajamim 'sabio(s), rabino(s)' (hb. מכם, סכממים)

hakipurim vid. Yom

halá 'parte de la masa del pan que, como ofrenda, es preceptivo separar y quemar antes de hornearlo' (hb. מללה)

hamélej 'el Rey' (hb. המלך)

haquebarot vid. bet

SEFARAD, vol. 72:2, julio-diciembre 2012, págs. 389-429. ISSN: 00037-0894. doi: 10.3989/sefarad.012.012 
harác vid. yéŝer

hasidut 'piedad, devoción' (hb. ססידות)

haŝîisá 'barrera, obstáculo' (hb. מאיצה)

hataḅácat vid. mipí

hayayab: ser 'ser reo de, estar obligado a llevar a cabo una reparación (por haber cometido un pecado)' (hb. סייב)

hejréaḥ 'necesidad' (hb. הכלס)

heter 'permiso, autorización rabínica' (hb. התר)

hịáá 'fervor, amor' (hb. מיבה)

hojmá 'sabiduría' (hb. סככמה)

hali 'enfermedad' (hb. מול מלמל)

ḥupá 'baldaquino o palio nupcial bajo el cual se sitúan los novios en las bodas', por extensión 'boda' ( $h$ b. סופה); entrar a_la 'casarse'

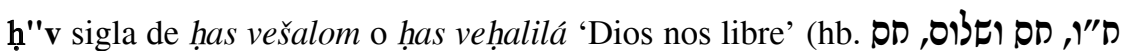
ומלילה

'icar 'esencial' (hb. עיקר)

'inián 'asunto, argumento' (hb. עצין)

intimar 'fijar, determinar'

isur 'prohibición' (hb. איסור), gamur 'prohibición absoluta' (hb. איסור גמנור)

kabod 'honor, honra' (hb. כלבוד)

karet 'excomunión, castigo divino, muerte prematura' (hb. כנכרת)

kašer, fm. kešerá 'lícito(a), apto(a)' (hb. כשכר, כשרה)

kelal 'nada de nada, en absoluto' (hb. לכל)

kelí 'cacharro, utensilio' (hb. כל')

kešerá vid. kašer

kétem 'mancha' (hb. כתס)

Kipur vid. Yom hakipurim

kol šekén 'con tanta más razón, a fortiori' (hb. כל שכן)

lebatalá vid. źera'

lidé: venir 'venir a, incurrir en (el pecado que luego se señala)' (hb. ליד)

liĵas 'termas, baños, balnearios' (sc. sing. ïlìdža, ìlidža, tc. ılıca)

lugo 'en seguida, inmediatamente'

ma 'pero' (it. $m a$ )

ma'asé 'suceso, relato' (hb. מעשה) 
macom: otó 'aquel lugar' (hb. אותו מקום): vid. notas 38 y 51.

mamáš 'realmente, propiamente' (hb. מתמ סמקמש)

manías 'pulseras'

mañera 'estéril'

mašal 'ejemplo' (hb. מצשל)

matir: ser 'autorizar, permitir' (hb. ממתיר)

mayorgarse 'hacerse fuerte'

meḥamat 'a causa de, porque' (hb. ממסמת)

melajot 'trabajos, tareas' (hb. מלאלות)

meldador 'lector'

meldar 'leer'

merḥáŝ 'baño público' (hb. מכרסץ)

micvé 'baño ritual' (hb. מקוה)

mijnasáyim 'pantalones' (hb. מכנסיים)

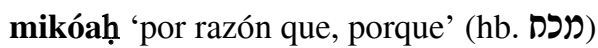

mikol vajol 'completamente' (hb. מכל וכל ) מכל המל)

milá 'circuncisión' (hb. מעילה)

minhag 'uso, costumbre' (hb. מנתינה)

mipí hatabáa 'at 'del ano, culo’ (hb. lit. 'de la boca del anillo' מפי הטבעת)

miŝvá, pl. miŝvot 'precepto(s)' (hb. מצוה, מצות)

MoHaRa"M sigla de Morenu HaRab Riḅí Mošé 'nuestro maestro rabino Mošé' (מהכ"סס): vid. nota 58.

moŝé: Tišcá beab, T"'b 'al terminar el día 9 del mes de ab' (hb. lit. 'salidas'

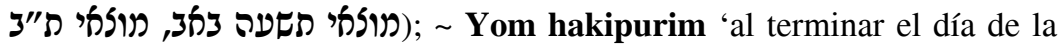
expiación' (מולאאי יום הכפורים): vid. Tišá, Yom

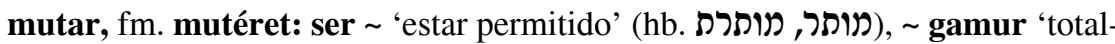
mente permitido' (hb. מצותר גמור)

našim 'mujeres' (hb. נשים)

nebonim 'sabios' (hb. נצונים)

niḍá 'impura; (mujer) menstruante; apartada' (hb. פידה): vid. notas 28 y 30.

niḍut vid. dam

nisuín 'esponsales' (hb. פשואין)

oc' abrev. de ocas: cierta medida de peso (tc. sing. okka)

ofen 'modo, manera' (hb. אופן): vid. bešum 
'olam 'la gente, todo el mundo' (hb. עולם): vid. šeḅa'olam

oluques 'canalones' (tc. sing. oluk)

'oná 'cópula, acto sexual' (hb. עונה): vid nota 55.

ones ‘coacción, compulsión' (hb. אונס)

orejales 'pendientes'

otó vid. macom

pasuc 'versículo' (hb. פסקו)

pašut 'simple' (hb. פשות)

peñarse 'peinarse'

periyá urbiyá 'procreación, relaciones sexuales' (hb. lit. 'reproducción y multiplicación' פריה ולביה)

peśgado 'grave'

por_que tb. 'para que'

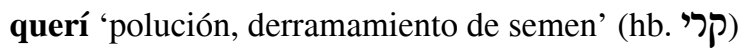

rabá fm. sing. 'grande' (hb. לכבה)

raquí 'aguardiente' (sc. ràkija, tc. rakı)

rašé tebot 'abreviatura, iniciales' (hb. כסאשי תיבות)

raúy 'apto' (hb. לסאוי)

Reubén 'Mengano' (hb. lit. 'Rubén' רסובאן)

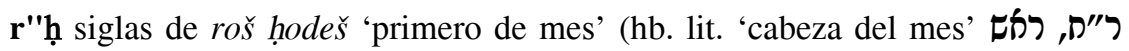
(סוד)

rob 'mayoría' (hb. לרוב)

roš vid. calut

šaḅat 'sábado' (hb. שָבת)

safec 'duda, sospecha' (hb. ספתק)

šalíặ 'enviado' (hb. של שמלס)

šama'ti 'escuché' (hb. שמעמתי)

sandéquet 'mujer que entrega el niño al sandac, padrino, que sostiene al niño durante la circuncisión' (hb. סנדקת)

šebạolam vid. bešum

sefirá 'cuenta, cómputo' (hb. ספירה)

segulá 'remedio, cura' (hb. סגaלה): vid. nota 53.

sehoc ‘risa, diversión' (hb. שמסוק)

sekaná 'peligro' (hb. סכנה) 
šekén vid. kol

se', seño' abrev. de señor( $a$ )

seni'ut 'modestia' (hb. Sפיעות)

se'ud' abrev. de se 'udá 'comida festiva, banquete' (hb. סעעודה)

siḅá 'causa, razón' (hb. סיבה)

simán 'señal' (hb. סימן)

ši 'úr 'medida; de tal manera; en cantidad' (hb. שיעוך)

Sukot: fiesta de las Cabañuelas, en que se conmemora la travesía de los israelitas por el desierto durante 40 años, habitando en tiendas o tabernáculos; comienza el 15 de tišrí y dura una semana, en la que es preceptivo sentarse a comer en la suká (hb. סוכות)

שי"ת' יתברך)

tacsar 'tasar, determinar'

talit 'taled', prenda a modo de chal de lana o de seda con que los judíos se cubren en determinadas ceremonias religiosas (hb. טלית)

taná 'tanaíta, cada uno de los tanaím, rabinos de la Ley oral cuyas opiniones y decisiones están recogidas en la Mišná' (hb. תנמ)

tas 'cuenco, tazón de metal' (fr. tasse, sc. täs, tc. tas)

tašmíš 'relaciones sexuales' (hb. lit. 'uso [de la cama]' תשמיש)

tavayol 'paño, trapo' (it. tovagliolo)

T'b vid. Tišcá beab

teba' 'naturaleza, caracter' (hb. טכע)

tebilá abrev. tebil' 'baño ritual por inmersión (acto); baño ritual (lugar)' (hb. טבילה), tomar 'bañarse, lavarse'

tebot vid. rašé

tefilín 'filacterias' (hb. תפילין)

teneché 'hojalata' (sc. tenèce, tanècé, tenècáa, tc. teneke)

tenplar 'mezclar; servir'

Tišcá beab, siglas T'b: 9 del mes de ab, día de ayuno mayor en el que se rememora la destrucción del Templo y otras calamidades de la historia judía (hb. תשעה באזב, ת"ב): vid. ‘éreb, moŝé

tornar 'volver a hacer algo, repetir una acción' (se usa como locución adverbial 'de nuevo')

tumá 'impureza' (hb. טמאמאה) 
urbiyá vid. periyá

vaday 'ciertamente, por supuesto, con seguridad' (hb. ודאוד)

vején 'y así' (hb. וכי)

véset 'menstruación, ciclo menstrual' (hb. וסקת)

y tb. 'también'

yeradas 'equivocadas'

yerar 'errar, equivocarse, no cumplir'

yéser 'pasión, deseo' (hb. יצר), harác 'mal instinto' (hb. יצר הכע)

Yom hakipurim, Kipur 'Día de la expiación', nombre de la más solemne y respetada festividad del año, dedicada al arrepentimiento y a la expiación de los pecados (hb. יוס הכפורים, כפור): vid. 'éreb, moŝé

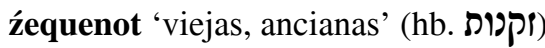

źera' 'semen' (hb. זכע), lebatalá 'derramamiento de semen (no con propósito

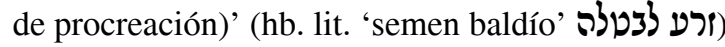

ź"I siglas de źijronam librajá 'bendita sea su memoria [de ellos]', dícese de quienes ya han muerto (hb. מכרונם לברכה)

Recibido: $12 / 05 / 2012$

Aceptado: 26/11/2012 